\title{
COVID-19, SARS and Bats Coronaviruses Genomes Unexpected Exogenous RNA Sequences
}

Jean Claude Perez, Luc Montagnier

\begin{abstract}
Jean-Claude Perez, PhD Maths § Computer Science Bordeaux University, RETIRED interdisciplinary researcher (IBM Emeritus, IBM European Research Center on Artificial Intelligence Montpellier), Bordeaux metropole, France
\end{abstract}

Luc Montagnier, Paris, France

\begin{abstract}
:
We are facing the worldwide invasion of a new coronavirus. This follows several limited outbreaks of related viruses in various locations in a recent past (SARS, MERS). Although the main objective of researchers is to bring efficient therapeutic and preventive solutions to the global population, we need also to better understand the origin of the newly coronavirus-induced epidemic in order to avoid future outbreaks. The present molecular appraisal is to study by a bio-infomatic approach the facts relating to the virus and its precursors.

This article shows how 16 fragments (Env Pol and Integrase genes) from different strains, both diversified and very recent, of the HIV1, HIV2 and SIV retroviruses most likely are present into the genome of COVID19. Among these fragments, 12 are concentrated in a very small region of the COVID-19 genome, length less than 900 bases, i.e. less than $3 \%$ of the total length of this genome. In addition, these footprints are positioned in 2 functional genes of COVID-19: the orf1ab and S spike genes.

To sum up, here are the two main facts which contribute to our hypothesis of a partially synthetic genome: A contiguous region representing $2.49 \%$ of the whole COVID- 19 genome of which $40.99 \%$ is made up of 12 diverse fragments originating from various strains of HIV SIV retroviruses. On the other hand, these 12 fragments some of which appear concatenated.
\end{abstract}

Notably, the retroviral part of these regions, which consists of 8 elements from various strains HIV1, HIV2 and SIV covers a length of 275 contiguous bases of COVID-19. The cumulative length of these 8 HIV SIV elements represents 200 bases. Consequently, the HIV SIV density rate of this region of COVID-19 is $200 / 275=72.73 \%$, which is considerable s made of. Moreover each of these elements is made of 18 or more nucleotides and therefore may have function. They are called Exogenous Informative Elements.

A major part of these 16 EIE already existed in the first SARS genomes as early as 2003. However, we demonstrate how and why a new region including 4 HIV1 HIV2 Exogenous Informative Elements radically distinguishes all COVID-19 strains from all SARS and Bat strains.

We then gather facts about the possible origins of COVID_19. We have particularly analyzed this small region of 225 bases common to COVID_19 and batRaTG13 but totally absent in all SARS strains.

Then, we discuss the case of bat genomes presumed to be at the origin of COVID_19. In the strain of bat RaTG13 coronavirus isolated in 2013, then sequenced in 2020, the homology profile for HIV1 Kenya 2008 fragment is identical to that of COVID_19.

Finally, we have studied the most recent genetic evolution of the COVID_19 strains involved in the world epidemic. We found a significant occurrence of mutations and deletions in the $225 \mathrm{~b}$ region.

On sampling genomes, we finally show that this $225 \mathrm{~b}$ key region of each genome, rich in EIE, evolves much faster than the corresponding whole genome.

The comparative analysis of the SPIKES genes of COVID_19 and Bat RaTG13 demonstrates two abnormal facts: on the one hand, the insertion of 4 contiguous amino acids in the middle of SPIKE, on the other hand, an abnormal distribution of synonymous codons in the second half of SPIKE. Finally the insertion in this region of an EIE coming from a Plasmodium Yoelii gene is demonstrated, but above all seems to explain the "strategy" pursued by having "artificially" modified the ratio of synonym codons / non-synonymous codons in this same region of 1770 COVID_19 SPIKE nucleotides. 


\section{INTRODUCTION :}

We are facing the worldwide invasion of a new coronavirus. This follows several limited outbreaks of related viruses in various locations in a recent past [1,2]. The human civilization has been very successful in the last centuries regarding demographic and economic growths. However, in our times, the economic power is concentrated in the hands of a few individuals and consequently economic interests are prevailing over the well being of humanity.

Although the main objective of researchers is to bring efficient therapeutic and preventive solutions to the global population, we also need to better understand the origin of the new coronavirus-induced epidemic in order to avoid future outbreaks. The present molecular appraisal is to study by a bio-infomatic approach the facts relating to the virus and its precursors.

We had analyzed the evolution of coronaviruses from the first SARS (2003), to the first genomes of COVID19 , when it was still called 2019-nCoV [3]. It is then that we read this online article « On the origins of the 2019 ncov virus wuhan china » [4] according to which a region of around $1 \mathrm{~kb}$ is totally new in the genome of COVID19.

Using our proprietary bio-mathematic approach we are able to evaluate the level of cohesion and organization of a genome, we discovered that the deletion by mutation of this new region of $1 \mathrm{~kb}$ [4] would increase the level of « structural harmonization » of the genome.

This suggests that this exogenous " addition » to the genome. Upon studying the publication of Prashang et al . [15] we then searched in this genome for possible traces of HIV or even SIV. A first publication [5] reports the discovery if 6 HIV SIV RNA pieces relates to crucial retroviral genes like Enveloppe and RT Pol. The present article confirms and extends these initial results.

\section{MATERIALS and METHODS :}

Access to data banks :

Preliminary Note :

The COVID-19 genome sequence initially studied in this article is NC 045512.2 .More generally, we are interested in the first genomes published under the reference "Wuhan market". However, these sequences published in January 2020 evolved somewhat during the first quarter of 2020. Thus, $\underline{\mathrm{NC}} \mathbf{0 4 5 5 1 2 . 2}$

has evolved from 29866b to 29903b without its GENBANK NCBI reference was changed.

All these sequences of genomes referenced "Wuhan market" relating to individual patients, were deposited on January 30, 2020 and then re-published on March 6, 2020. For these reasons we will have to specify and adjust here the addresses of the key regions "A" and "B " which we analyze in this article.

The Wuhan market referenced genomes are presently:

https://www.ncbi.nlm.nih.gov/nuccore/LR757995.1

https://www.ncbi.nlm.nih.gov/nuccore/LR757996.1

https://www.ncbi.nlm.nih.gov/nuccore/LR757997.1

https://www.ncbi.nlm.nih.gov/nuccore/LR757998.1

$\underline{\text { and }}$

https://www.ncbi.nlm.nih.gov/nuccore/NC 045512.2

Thus, the start address of the region of 330b named in this article "region B" which was initially positioned at $21673 \mathrm{~b}$ in our previous article is now shifted at 21698b in NC 045512.2 , at 21683b in LR757995.1, at 21678b in LR757996.1, and at 21673b in LR757998.1. The sequence LR757997.1, is unavailable because it contains more than 10,000 indeterminate « $N$ » bases.

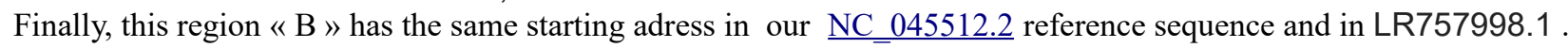

The reference sequence used in this article is : https://www.ncbi.nIm.nih.gov/nuccore/LR757998.1

\section{We use as reference the former referenced genome : Wuhan market ID: LR757998.1}

Validation of nucleotide fragments as " Exogenous Informative Elements » (EIE) :

We have chosen this minimal length of 18 nucleotides ( 6 amino acids) for the support of information ( thus as an antigenic motif ). This is also the size of the primers used for PCR which allows high specificity of sequence selection on DNA recognition. 


\section{Main COVID_19 genes involved :}

The two main genes involved in COVID-19 genome are Orf1ab and « S » Spike.

Their relative adresses in our referenced genome are :

266. 21555. Orf1ab

21563..25384. S spike

The main analyzed regions :

Region « A », Location of the 600bases from COVID_19 reference genome Wuhan market ID: LR757998.1.

Their length was between 21072 and 21672 nucleotides.

AGGGTTTTTTCACTTACATTTGTGGGTTTATACAACAAAAGCTAGCTCTTGGAGGTTCCGTGGCTATAAAGATAACAGAACATTCTTGGA ATGCTGATCTTTATAAGCTCATGGGACACTTCGCATGGTGGACAGCCTTTGTTACTAATGTGAATGCGTCATCATCTGAAGCATTTTTAATT GGATGTAATTATCTTGGCAAACCACGCGAACAAATAGATGGTTATGTCATGCATGCAAATTACATATTTTGGAGGAATACAAATCCAATTC AGTTGTCTTCCTATTCTTTATTTGACATGAGTAAATTTCCCCTTAAATTAAGGGGTACTGCTGTTATGTCTTTAAAAGAAGGTCAAATCAAT GATATGATTTTATCTCTTCTTAGTAAAGGTAGACTTATAATTAGAGAAAACAACAGAGTTGTTATTTCTAGTGATGTTCTTGTTAACAACTA AACGAACAATGTTTGTTTTTCTTGTTTTATTGCCACTAGTCTCTAGTCAGTGTGTTAATCTTACAACCAGAACTCAATTACCCCCTGCATA CACTAATTCTTTCACACGTGGTGTTTATTACCCTGACAAAGTTTTCAGATCC

see details alignment in supplementary materials « $\mathrm{a} »$.

Region «B », Location of the 330 first bases from COVID_19 reference genome Wuhan market ID: $\underline{\text { LR757998.1. }}$

Their length was between 21672 and 22002 nucleotides (then immediately following region « A » :

TCAGTTTTACATTCAACTCAGGACTTGTTCTTACCTTTCTTTTCCAATGTTACTTGGTTCCATGCTATACATGTCTCTGGGACCAATGGT ACTAAGAGGTTTGATAACCCTGTCCTACCATTTAATGATGGTGTTTATTTTGCTTCCACTGAGAAGTCTAACATAATAAGAGGCTGGATT TTTGGTACTACTTTAGATTCGAAGACCCAGTCCCTACTTATTGTTAATAACGCTACTAATGTTGTTATTAAAGTCTGTGAATTTCAATTTT GTAATGATCCATTTTTGGGTGTTTATTACCACAAAAACAACAAAAGTTGGATGGAAAGT

see details alignment in supplementary materials « b ».

We analyzed this larger region which starts at the same address as our region "B" :

entitled « Region Lyons-Weiler » [4].

Their length was between 21672 and 23050 (1378 nucleotides) within reference genome Wuhan market ID: $\underline{\text { LR757998.1 }}$

In the RESULTS and DISCUSSION, we will more particularly analyze a small region of 225 nucleotides located between the bases. and. of the reference genome:

TGTTTTTCTTGTTTTATTGCCACTAGTCTCTAGTCAGTGTGTTAATCTTACAACCAGAACTCAATTACCCCCTGCATACACTAATTCTTTC ACACGTGGTGTTTATTACCCTGACAAAGTTTTCAGATCCTCAGTTTTACATTCAACTCAGGACTTGTTCTTACCTTTCTTTTCCAATGTT ACTTGGTTCCATGCTATACATGTCTCTGGGACCAATGGTACTAA

Alignments : Analysing COVID-19 DNA sequences, We use BLAST NCBI public tool.

BLASTn - NIH

NCBI National Center for Biotechnology Information.

https://blast.ncbi.nlm.nih.gov/Blast.cgi?PAGE_TYPE=BlastSearch

Relating the " DNA Master Code », a biomathematic method to analyse cohesion/heterogeneity of a DNA sequence:

Full details on this numerical method in [6-8], and recall Methods in supplementary Materials2 « $\mathrm{m} »$.

we must introduce and summarize this theoretical method, because its constitutes a strong way to illustrate crucial differences between COVID_19 and bat RaTG13 specific genomes (Figures 4 and 5).

Full details on this numerical method in [6-8], and recall Methods in supplementary Materials «1». 
Starting from the atomic masses of the C O N H S P bioatoms constituting RNA, DNA nucleotides and amino acid, a simple law of projection of these atomic masses leads to a UNIFICATION of GENOMICS and PROTEOMICS patterned images that can be calculated for any DNA/RNA codons sequence. This numerical projection of atomic masses produces a whole numbers numerical code common to the triplets codons DNA, RNA, or amino acids. A process of DIGITAL INTEGRATION at short, medium and very long distance then allows a globalization of genetic information by a principle which recalls an analogy with the HOLOGRAM. "Thus, any codon radiates at long distance and vice versa ». The Master Code of this sequence then produces two signatures, one GENOMIC, the other for PROTEOMIC, materialized by 2 very strongly correlated curves. that is this level of coupling which will provide precious information on the COHESION or on the HETEROGENEITY [11] of this nucleotide sequence. in particular the extreme regions (mini / maxi) would be associated with biological functions such as active sites, chromosomes breakpoints, etc.

Dynamics of COVID_19 sequences available:

We will specify that this study having been carried out over several weeks at the time when the number of genomes COVID_19 was constantly evolving, we saw fit to specify, each time in eital characters, the dates of the BLASTn searches as well as the number of sequences available at this exact moment.

\section{RESULTS and DISCUSSION :}

This RESULTS and DISCUSSION section will have 4 main sections:

\section{Part I/IV}

18 RNA fragments of homology equal or more than $80 \%$ with human or simian retroviruses have been found in the COVID_19 genome. These fragments are 18 to 30 nucleotides long and therefore have the potential to modify the gene expression of Covid19. We have named them external Informative Elements or EIE. These EIE are not dispersed randomly, but are concentrated in a small part of the genome.

\section{Part II/IV}

This region, a 225 nucleotide long region is unique to COVID_19 and Bat RaTG13 and can discriminate and formally distinguish these 2 genomes.

Part III/IV

In the decreasing slope of the epidemic, this 225 bases region exhibits an abnormally high rate of mutations/deletions, particularly in USA WA state (Seattle).

Part IV/IV

The comparative analysis of the SPIKES genes of COVID_19 and Bat RaTG13.

\section{Part I/III}

18 RNA fragments of homology equal or more than $80 \%$ with human or simian retroviruses have been found in the COVID_19 genome. These fragments are 18 to 30 nucleotides long and therefore have the potential to modify the gene expression of Covid19. We have named them external Informative Elements or EIE. These EIE are not dispersed randomly, but are concentrated in a small part of the genome. 
Warning: on the limits of bioinformatics tools like BLASTn: the main criticism that this article will have to face

is that of the relevance of our BLASTn analyzes highlighting many small traces of HIV in the genome of

COVID_19. We will answer with the following 3 facts:

$1 /$ We limit the HIV fragments selected to a minimum of 18 bases to consider them as relevant.

2 / To counter arguments of the non-significant BLASTn "E-value" type (like " the E-value of 315 means that you can expect 315 hits like that purely by chance. ") etc ... we will respond with this old article from 2004 published in Hong Kong [25] according to which the SARS Spike gene and the HIV GP41 gene would have a very strong analogy of $3 D$ resemblance.

3 / Today, technologies such as CRISPR-Cas13 RNA [23] make it possible to modify RNA sequences with clockmaker precision capable of placing exogenous sequence fragments "side by side" as we will demonstrate here.

\section{1- A high density of HIV SIV regions that are diverse both in their nature and in their collection dates: indeed, a concentration of 12 significant HIV SIV EIE in only 744 bases.}

We are now looking for possible traces of HIV1, HIV2 or SIV EIE into our Wuhan market reference genome LR757998.1.

We will only use as significant EIE those which have at least 18 nucleotides of homology, i.e. 6 codons.

Note: We will present below $12+4$ HIV/SIV EIE in the sequential order of their addresses within COVID_19 genome.

However, it is worth recalling here the history of successive discoveries from these regions. Initially, by focusing on the genome region mentioned in [4], we discovered and published [5] 6 first EIE located at the very beginning of this region.

By a more in-depth exploration of this region (region "B" 330b), then exploring region " $A$ "

(of 600b) immediately located upstream of this region "B ", we discover, concentrated on less than 930b, 12 HIV SIV EIE. We complete them with the last 4 EIE located upstream in the genome. It is this set of 16 EIE which will be detailed below.

\section{Evidence for 12 HIVISIV EIE sequences in regions "A" and "B" of COVID-19 genome:}

Following, the 14 HIV/SIV "Exogenous Informative Elements":

==> ==> BLASTn detailed scans are in Supplementary Materials (Ref1).

Region A : 600b (21072 to 21672)

Details:

Hiv2. France (2012) 66-81

Hiv1 Sweden (2017) 154-174

Hiv2 Guinea (2012) 236-253

SIV Africa (2016) $\quad 366-386$

Region B : 330b (21672 to 22002)

Details:

Hiv2. Côté ivoire (2014) 23. 42

Siv Tanzania (2016) 2950 partial overlap

Siv p18. (2016) 7796 *

Hiv1. Netherlands (2016) . 85. 112. Usa 85108 *

Hiv2 UC1. Cote d'Ivoire 1993) $132157^{*}$

Hiv2 Sénégal. (2011) 179194 *

Hiv1 Malawi. (2013) 212243 *

Hiv1. Russia. (2010) 242280 * 
SivagmTan Cameroun (2015) 279298 *

We consider only the $8\left({ }^{*}\right)$ HIV SIV motifs, the $9^{\text {th }}$ is partially in overlap.

These 14 HIV SIV -EIE- are detailed I SUPPLEMENARY MATERIALS (ref 1).

So, to sum up these 14 HIV SIV signatures, here is Table1:

Table 1 - Synoptic table of 12 significant EIE from HIV SIV strains in the "A" and "B" regions of the COVID-19 genome.

\begin{tabular}{|c|c|c|c|c|c|c|c|c|c|}
\hline Origines & $\begin{array}{l}\text { HIV } \\
\text { SIV } \\
\text { type }\end{array}$ & $\begin{array}{l}\text { Relative } \\
\text { Location }\end{array}$ & $\begin{array}{l}\text { «Exogenous Informative Element» } \\
\text { Label }\end{array}$ & Access & Homology & $\begin{array}{l}\text { Bases } \\
\text { identities }\end{array}$ & $\begin{array}{l}\mathrm{O} \\
\mathrm{R} \\
\mathrm{F} \\
1 \\
\mathrm{a} \\
\mathrm{b}\end{array}$ & $\begin{array}{l}\mathrm{S} \\
\mathrm{s} \\
\mathrm{p} \\
\mathrm{i} \\
\mathrm{k} \\
\mathrm{e}\end{array}$ & $\begin{array}{l}\text { Real } \\
\text { location }\end{array}$ \\
\hline \multicolumn{10}{|c|}{ Region A $600 \mathrm{~b}: 21072$ to 21672} \\
\hline \multicolumn{10}{|c|}{ 266. 21555. Orf1ab. Relative locations 484/600 (end Orf1ab gene), } \\
\hline $\begin{array}{l}2012 \\
\text { France }\end{array}$ & HIV2 & $66-81$ & $\begin{array}{l}\text { HIV-2 isolate } 56 \text { from } \begin{array}{r}\text { France } \\
\text { envelope glycoprotein } \\
\text { gene, partial cds }\end{array}\end{array}$ & $\begin{array}{l}\text { JN230 } \\
\underline{738.1}\end{array}$ & $\begin{array}{l}100,00 \% \\
\underline{\text { Unsignific }} \\
\underline{\text { ant }}\end{array}$ & $\begin{array}{l}16 / 16 \\
\underline{\text { Unsignif }} \\
\underline{\text { icant }}\end{array}$ & $\S$ & & $\begin{array}{l}21137 \\
21152\end{array}$ \\
\hline $\begin{array}{l}2017 \\
\text { Sweden }\end{array}$ & HIV1 & $154-174$ & $\begin{array}{l}\text { HIV-1 isolate 060SE from } \\
\text { Sweden, partial genome }\end{array}$ & $\begin{array}{l}\underline{\mathrm{MF3}} \\
\frac{7316}{\underline{3.1}} \\
\end{array}$ & $100,00 \%$ & $21 / 21$ & $\S$ & & $\begin{array}{l}21225 \\
21245\end{array}$ \\
\hline $\begin{array}{l}2012 \\
\text { Guinea }\end{array}$ & HIV2 & $236-253$ & $\begin{array}{l}\text { HIV-2 isolate CA65410.13 from } \\
\text { Guinea-Bissau envelope gene, partial } \\
\text { cds }\end{array}$ & $\begin{array}{l}\text { JN86 } \\
\underline{3831 .} \\
\underline{1}\end{array}$ & $94,00 \%$ & $17 / 18$ & $\S$ & & $\begin{array}{l}21307 \\
21324\end{array}$ \\
\hline $\begin{array}{l}2016 \\
\text { Africa }\end{array}$ & SIV & $366-386$ & $\begin{array}{l}\text { Simian immunodeficiency virus } \\
\text { isolate VSAA2001, complete } \\
\text { genome }\end{array}$ & $\begin{array}{l}\underline{\text { KR86 }} \\
\underline{2351 .} \\
\underline{1}\end{array}$ & $95,00 \%$ & $20 / 21$ & $\S$ & & $\begin{array}{l}21437 \\
21457\end{array}$ \\
\hline \multicolumn{10}{|c|}{ 21563..25384. S spike } \\
\hline $\begin{array}{l}2008 \\
\text { Kenia } \\
{[9]}\end{array}$ & HIV1 & $471-501$ & $\begin{array}{l}\text { HIV-1 clone ML1592n from Kenya } \\
\text { nonfunctional vpu protein (vpu) } \\
\text { gene, complete sequence; and } \\
\text { nonfunctional } \\
\text { glycoprotein (env) gene, partial } \\
\text { sequence }\end{array}$ & $\begin{array}{l}\underline{\text { EU87 }} \\
\underline{5177 .} \\
1\end{array}$ & $88,00 \%$ & $28 / 32$ & $\S$ & $\S$ & $\begin{array}{l}21542 \\
21572\end{array}$ \\
\hline $\begin{array}{l}2012 \text { Cap } \\
\text { verde }\end{array}$ & HIV2 & $512-529$ & $\begin{array}{l}\text { HIV-2 isolate 05HANCV37 from } \\
\text { Cape Verde envelope glycoprotein } \\
\text { (env) gene, partial cds }\end{array}$ & $\begin{array}{l}\underline{\mathrm{JF} 26} \\
\underline{7434 .} \\
\underline{1}\end{array}$ & $100,00 \%$ & $18 / 18$ & & $\S$ & $\begin{array}{l}21583 \\
21600\end{array}$ \\
\hline \multicolumn{10}{|c|}{ Region B : 330p (21672 to 22002) } \\
\hline $\begin{array}{l}2014 \\
\text { Cote }\end{array}$ & HIV2 & $23-42$ & $\begin{array}{l}\text { HIV-2 isolate 106CP_RT from } \\
\text { Cote d'Ivoire reverse }\end{array}$ & $\underline{\mathrm{KJ} 13}$ & $95,00 \%$ & $19 / 20$ & & $\S$ & $\begin{array}{l}21694 \\
21713\end{array}$ \\
\hline
\end{tabular}




\begin{tabular}{|c|c|c|c|c|c|c|c|c|}
\hline d'ivoire & & & transcriptase gene, partial cds & $\frac{1112 .}{1}$ & & & & \\
\hline $\begin{array}{l}2016 \\
\text { Tanzania } \\
\text { Partially } \\
\text { overlap }\end{array}$ & SIV & $29-50$ & $\begin{array}{l}\text { Simian immunodeficiency virus } \\
\text { isolate TAN5 from Tanzania, } \\
\text { complete genome }\end{array}$ & $\frac{\frac{\text { AF00 }}{3044 .}}{1}$ & $91,00 \%$ & $20 / 22$ & $\S$ & $\begin{array}{l}21700 \\
21721\end{array}$ \\
\hline $\begin{array}{l}2016 \\
\text { Africa }\end{array}$ & SIV & $77-96$ & $\begin{array}{l}\text { Simian immunodeficiency virus } \\
\text { isolate } P 18 \text { patient } \mathrm{P} 1, \text { gp120 (env) } \\
\text { gene, partial cds }\end{array}$ & $\frac{\mathrm{AF} 0}{\frac{0304}{4.1}}$ & $95,00 \%$ & $19 / 20$ & $\S$ & $\begin{array}{l}21748 \\
21767\end{array}$ \\
\hline $\begin{array}{l}2016 \\
\text { Netherla } \\
\text { nds }\end{array}$ & HIV1 & $85-112$ & $\begin{array}{l}\text { HIV-1 isolate 19828.PPH11 from } \\
\text { Netherlands envelope glycoprotein } \\
\text { (env) gene, partial cds } \\
\text { Sequence ID: HQ644953.1 }\end{array}$ & $\begin{array}{l}\frac{\text { HQ6 }}{4495} \\
\underline{3.1} \\
\end{array}$ & $89,00 \%$ & $25 / 28$ & $\S$ & $\begin{array}{l}21756 \\
21783\end{array}$ \\
\hline $\begin{array}{l}1993 \\
\text { côté } \\
\text { ivoire }\end{array}$ & HIV2 & $132-157$ & $\begin{array}{l}\text { Human immunodeficiency virus type } \\
2 \text { complete genome from strain HIV- } \\
\text { 2UC1 }\end{array}$ & $\underline{\underline{\mathrm{L} 076}}$ & $85,00 \%$ & $22 / 26$ & $\S$ & $\begin{array}{l}21803 \\
21828\end{array}$ \\
\hline $\begin{array}{l}2011 \\
\text { Sénégal }\end{array}$ & HIV2 & $179-194$ & $\begin{array}{l}\text { HIV-2 isolate } \\
\text { H2A62_111808_CINT_WBC_25 } \\
\text { from Senegal pol gene, partial } \\
\text { sequence }\end{array}$ & $\frac{\frac{\mathrm{JF} 81}{1228 .}}{1}$ & $\begin{array}{l}100,00 \% \\
\text { Unsignifica } \\
\text { nt }\end{array}$ & $\begin{array}{l}16 / 16 \\
\text { Unsignif } \\
\text { icant }\end{array}$ & $\S$ & $\begin{array}{l}21850 \\
21865\end{array}$ \\
\hline $\begin{array}{l}2013 \\
\text { Malawi }\end{array}$ & HIV1 & $212-243$ & $\begin{array}{l}\text { HIV-1 isolate } \\
\text { 4045_Plasma_Visit1_amplicon9 } \\
\text { from Malawi envelope glycoprotein } \\
\text { (env) gene, complete cds }\end{array}$ & $\frac{\underline{\mathrm{KC} 1}}{\underline{8706}}$ & $88,00 \%$ & $28 / 32$ & $\S$ & $\begin{array}{l}21883 \\
21914\end{array}$ \\
\hline $\begin{array}{l}2010 \\
\text { russia }\end{array}$ & HIV1 & $242-280$ & $\begin{array}{l}\text { HIV-1 isolate 07.RU.SP-R497.VI.F5 } \\
\text { from Russia envelope glycoprotein } \\
\text { (env) gene, complete cds }\end{array}$ & $\begin{array}{l}\underline{\mathrm{GU} 4} \\
\underline{8145} \\
\underline{4.1}\end{array}$ & $82,00 \%$ & $32 / 39$ & $\S$ & $\begin{array}{l}21913 \\
21951\end{array}$ \\
\hline $\begin{array}{l}2015 \\
\text { Camero } \\
\text { un. }\end{array}$ & SIV & $279-298$ & $\begin{array}{l}\text { Simian immunodeficiency virus } \\
\text { partial pol gene for Pol, isolate } \\
\text { SIVagmTAN-CM545-pol }\end{array}$ & $\frac{\underline{\text { LM99 }}}{\underline{9945 .}}$ & $83,00 \%$ & $25 / 30$ & $\S$ & $\begin{array}{l}21950 \\
21969\end{array}$ \\
\hline
\end{tabular}

Note : « §» indicates in which COVID_19 gene is located each HIV / SIV EIE.

First, it is important to note that all the regions found here are included in one of the 2 main genes of

Evidence for 4 others HIVISIV EIE sequences in others areas of COVID-19 genome:

We also found 4 other non-contiguous HIV SIV regions summarized in Table 2 below. Details of these searches in the supplementary materials " $d$ ".

==> ==> BLASTn detailed scans related these 4 HIV SIV -EIE- are detailed in Supplementary Materials (ref 2).

Table 2 - Synoptic table of 4 gene EIE motifs from HIV SIV strains in others areas than the "A" and "B" regions of the COVID-19 genome.

\begin{tabular}{|c|c|c|c|c|c|c|c|c|c|c|}
\hline Origines & $\begin{array}{l}\text { HIV } \\
\text { SIV } \\
\text { type }\end{array}$ & Gene & $\begin{array}{l}\text { «Exogenous } \\
\text { Label }\end{array}$ & Informative & Elements » & Access & Homology & $\begin{array}{l}\text { Bases } \\
\text { identitie }\end{array}$ & $\begin{array}{l}\mathrm{O} \\
\mathrm{R} \\
\mathrm{F} \\
1\end{array}$ & \begin{tabular}{l|l}
$\mathrm{S}$ & $\begin{array}{l}\text { Real } \\
\text { location }\end{array}$ \\
$\mathrm{p}$ &
\end{tabular} \\
\hline
\end{tabular}




\begin{tabular}{|c|c|c|c|c|c|c|c|c|}
\hline & & & & & & & & \\
\hline \multicolumn{9}{|c|}{ 266. 21555. Orf1ab. } \\
\hline 2015 Germany & SIV & POL & $\begin{array}{l}\text { Simian immunodeficiency virus } \\
\text { isolate D4 from Germany gag } \\
\text { protein (gag) gene, complete cds; } \\
\text { pol protein (pol) gene, partial cds; } \\
\text { vif protein (vif), vpx protein (vpx), } \\
\text { vpr protein (vpr), tat protein (tat), } \\
\text { rev protein (rev), and envelope } \\
\text { glycoprotein (env) gene... }\end{array}$ & $\underline{\underline{\mathrm{KM} 37}}$ & $100,00 \%$ & $20 / 20$ & $\S$ & $\begin{array}{l}8751 \\
8770\end{array}$ \\
\hline 2016 China & HIV1 & ENV & $\begin{array}{lr}\text { HIV-1 clone } & \text { XJ47 } \\
\text { from China envelope } \\
\text { glycoprotein } \quad \text { (env) }\end{array}$ & $\begin{array}{l}\text { EU184 } \\
\underline{986.1}\end{array}$ & $87,00 \%$ & $33 / 38$ & $\S$ & $\begin{array}{l}14340 \\
14378\end{array}$ \\
\hline 2004 USA & HIV1 & $\begin{array}{l}\text { INTEG } \\
\text { RASE }\end{array}$ & $\begin{array}{l}\text { gene nartial cds } \\
\text { Homo sapiens clone } \\
\text { HIV1-H9-106 HIV-1 } \\
\text { intecration site }\end{array}$ & $\begin{array}{l}\text { AY516 } \\
986.1\end{array}$ & $93,00 \%$ & $26 / 28$ & $\S$ & $\begin{array}{l}20373 \\
20401\end{array}$ \\
\hline 2011 USA & HIV1 & ENV & $\begin{array}{l}\text { HIV-1 isolate JACH1853_A5 from } \\
\text { USA envelope glycoprotein (env) } \\
\text { gene, complete cds; and vpu } \\
\text { protein (vpu), rev protein (rev), and } \\
\text { tat protein (tat) genes, partial cds }\end{array}$ & $\begin{array}{l}\underline{\mathrm{HQ} 21} \\
\underline{7329.1}\end{array}$ & $93,00 \%$ & $28 / 30$ & $\S$ & $\begin{array}{l}20400 \\
20430\end{array}$ \\
\hline
\end{tabular}

Note : « $\S »$ indicates in which COVID_19 gene is located each HIV / SIV EIE.

Table 3 - The 16 HIV SIV EIE according to their homologies with COVID-19 sorted by decreasing $\%$.

\begin{tabular}{|c|c|c|}
\hline HIV SIV strain & COVID-19 gene & Homology \\
\hline HIV2 Env France 2012 ( & Orf1ab & $100,00 \%$ \\
\hline HIV1 Sweden 2017 (recombinant form in Sweden) & Orf1ab & $100,00 \%$ \\
\hline HIV2 Env Cap verde 2012 & S spike & $100,00 \%$ \\
\hline HIV2 Pol 2011 Senegal (unsignificant) & S spike & $100,00 \%$ \\
\hline SIV Pol 2015 Germany & Orf1ab & $100,00 \%$ \\
\hline SIV 2016 African Monkey & Orf1ab & $95,00 \%$ \\
\hline HIV2 RT Pol 2014 Cote d'ivoire & S spike & $95,00 \%$ \\
\hline SIV Env 2016 Africa & S spike & $95,00 \%$ \\
\hline HIV2Env 2012 Guinea & Orf1ab & $94,00 \%$ \\
\hline HIV1 Integrase 2004 USA & Orf1ab & $93,00 \%$ \\
\hline HIV1 Env 2011 USA & Orf1ab & $93,00 \%$ \\
\hline HIV1 Env 2016 Netherlands & S spike & $89,00 \%$ \\
\hline HIV1 Env 2008 Kenia & Orflab and & $88,00 \%$ \\
\hline HIV1 Env 2013 Malawi & S spike & $88,00 \%$ \\
\hline
\end{tabular}




\begin{tabular}{|l|r|l|}
\hline HIV1 Env 2016 China & Orf1ab & $87,00 \%$ \\
\hline HIV2 1993 Cote d'ivoire & S spike & $85,00 \%$ \\
\hline SIV Pol 2013 CAmeroon & S spike & $83,00 \%$ \\
\hline HIV1 Env 2010 Russia & S spike & $82,00 \%$ \\
\hline Average Homology $\%$ & 9 Orf1ab and $\mathbf{1 0}$ S spike & $\mathbf{9 2 . 6 1 \%}$ \\
\hline
\end{tabular}

\section{Synopsis of Homologies between COVD-19 and HIV1 HIV2 SV "EIE" motifs}

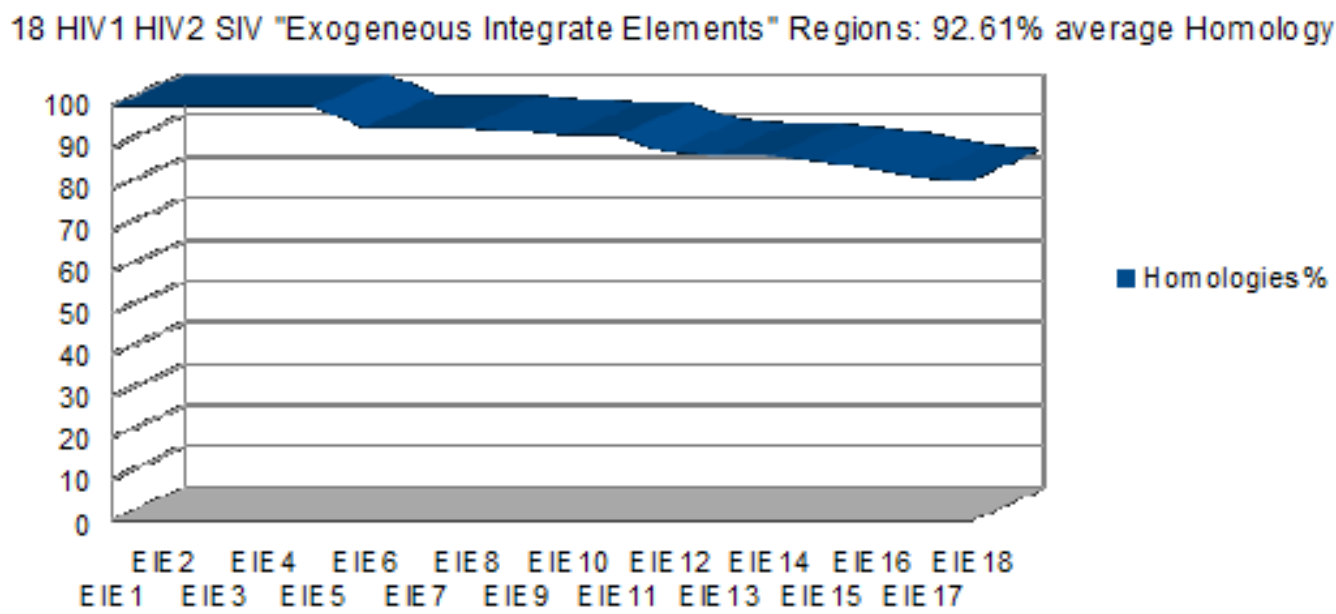

Figure 1 - The 18 HIV SIV EIE motifs according to their homologies with COVID-19 sorted by decreasing \%.

First, it is important to note that all the regions found here are included in one of the 2 main genes of COVID_19, so they are "Informative Exogenous Elements ». A synthetic chart is in Figure1.

Some significant results relating to this analyzed region of 930 base pairs $(600+330)$.

The entire genome has 29903 bases. The 12 regions are located between the bases 21225 and 21969 , that is to say exactly 744 bases.

This therefore represents an average space of $744 / 12=62$ bases for each EIE.

Or as a $\%$ of the whole genome $744 / 29903=2.49 \%$ of the whole genome.

As the cumulative length of the $12 \mathrm{EIE}$ is $305 \mathrm{~b}$, we deduce that the average size of an insert is $337 / 12=$ 25.4bases.

Finally, we deduce an occupancy rate of the 744bases space by EIE from HIV SIV of 25.4 / $62=\mathbf{4 0 . 9 9 \%}$.

This percentage is considerable.

So, to summarize: a contiguous region representing $2.49 \%$ of the whole COVID-19 genome is $40.99 \%$ made up of 12 diverse EIE originating from various strains of HIV SIV retroviruses. 


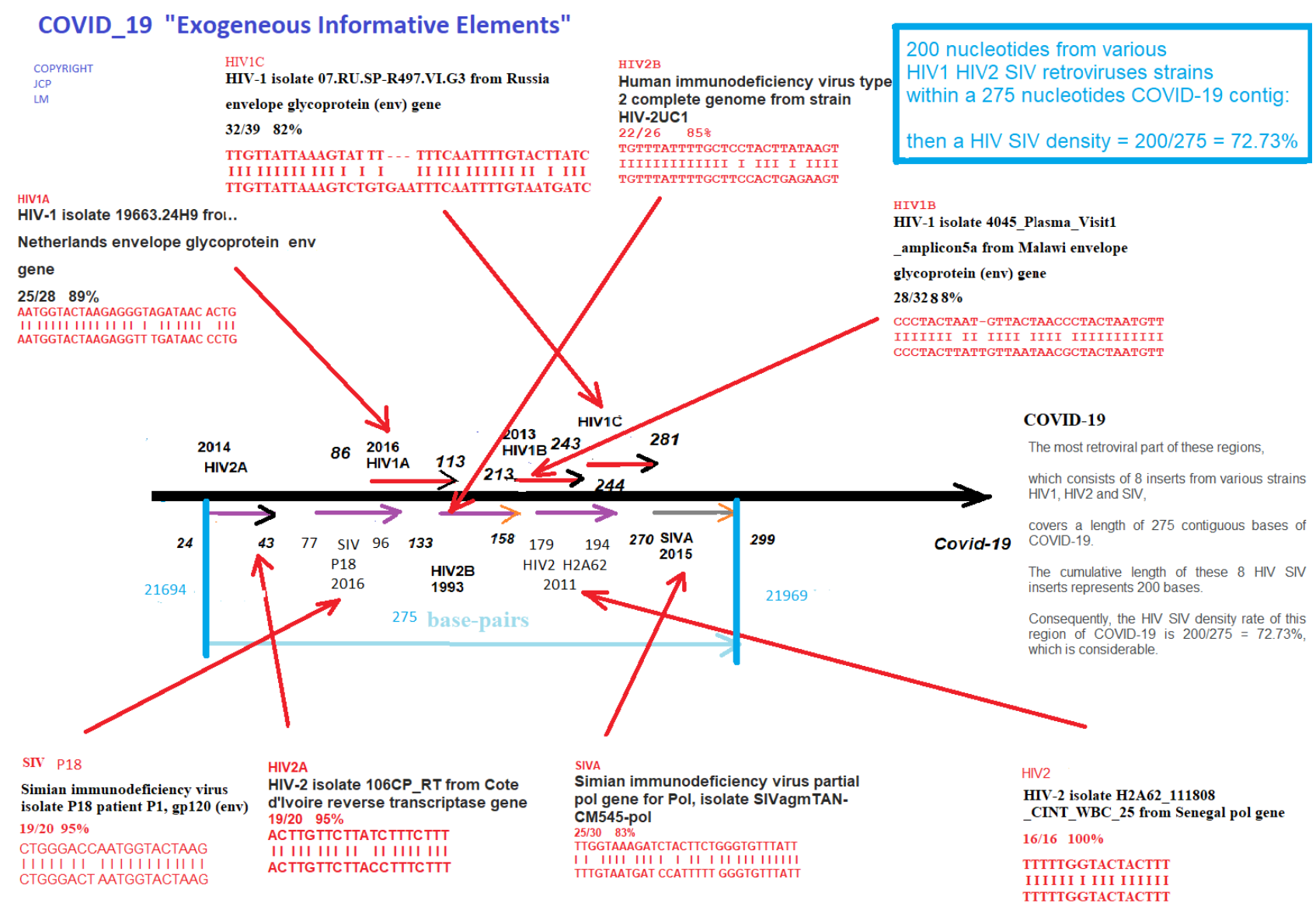

Figure 2 - This summary chart demonstrating how 200b from various HIV SIV retroviral strains within a concentrated $275 \mathrm{~b}$ COVID-19 contig have a density rate equal to $72.73 \%$.

\section{COVD-19 Genome HIV1 HIV2 SIV "Exogeneous Informative Eements"}

Comparative trends in HIV SIV densities and average cumulative ho mologies

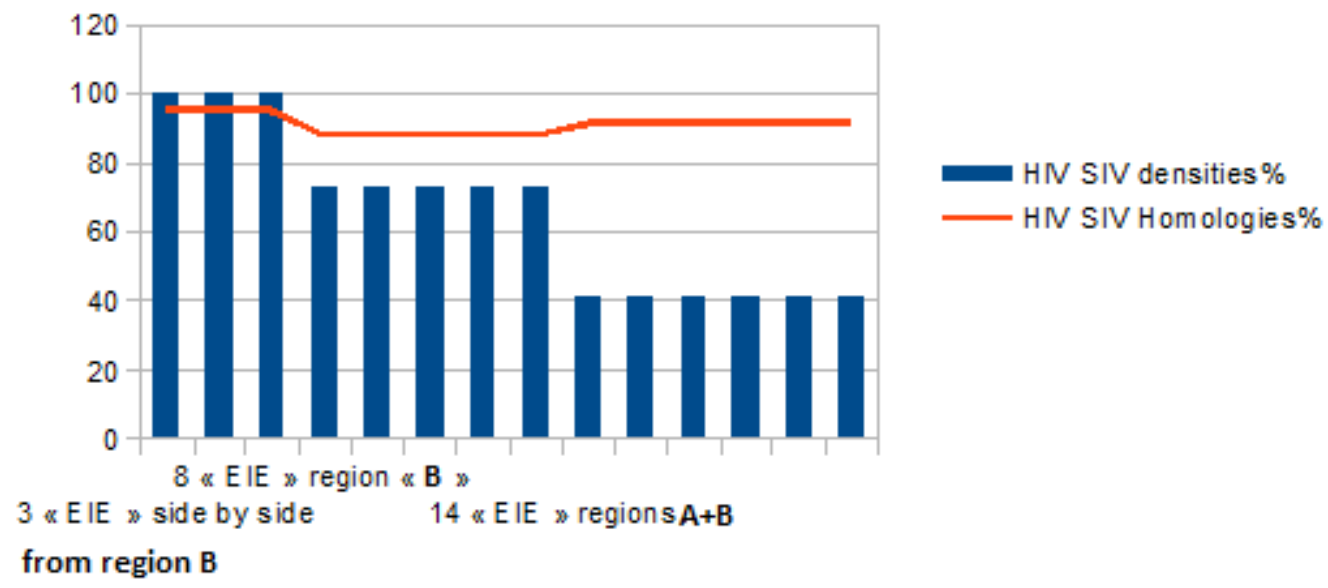

Figure 3 - Comparative trends in HIV/ SIV EIE densities (blue) and average cumulative homologies (red) for 3 clusters : the 3 region $\mathrm{B}$ EIE side by side, 8 EIE from region B, and all 14 EIE ( $\mathrm{A}+\mathrm{B}$ cumulated regions).

\section{2- Concatenations of HIV SIV regions "placed" in sequence and side by side.}

Table 2 shows two very different EIE follow each other side by side in the RNA sequence of COVID-19: 
The first, at addresses 20373 to 20401 comes from an HIV1 Integrase from a USA virus from 2004 ( Homo sapiens clone HIV1-H9-106 HIV-1 integration site, AY516986.1 ), while the second, at addresses 20400 to 20430 comes from an Envelope from another HIV1 virus from the USA from 2011 ( HIV-1 isolate JACH1853_A5 from USA envelope glycoprotein (env) gene, complete cds, HQ217329.1 ).

Even more surprising, in Table 1, we note the same phenomenon between, this time not 2 but 3 EIE from the radically different HIV SIV viruses:

Here are these 3 EIE concatenated with seemingly perfect " watchmaker's precision":

Malawi, year 2013.

HIV1 212-243 HIV-1 isolate

4045_Plasma_Visit1_amplicon9 Malawi envelope glycoprotein (approx) 88.00\% 28/32

Addresses: $2 \overline{18} 83 \quad \overline{21914}$

Russia, year 2010.

HIV1 242-280 HIV-1 isolate 07.RU.SP-R497.VI.F5 envelope glycoprotein Russia (env) gene 82.00\% 32/39

Addresses: 2191321951

Cameroon year 2015.

SIV 279-298 partial simian immunodeficiency virus pol gene for Pol, $83.00 \% 25 / 30$

Addresses: 2195021969

It will be observed that the cumulative length in COVID_19 of these 3 EIE is 126 bases for a number of HIV bases of 120 bases. Then a total HIV/COVID_19 of $120 / 126>95 \%$, which is remarkable.

\section{Part II/III}

\section{Among this part, a 225 nucleotide long region is unique to COVID_19 and Bat RaTG13 and can discriminate and formally distinguish these 2 genomes.}

The origin of COVID-19 remains an open question : see particularly [14-20] and [5].

In this second part of DISCUSSION and RESULTS, we will present two types of facts:

On the one hand, we will show that the 2 genomes of COVID_19 and Bat RaTG13 are exclusively distinguished from all the other genomes of SARS, MERS and other Bats.

On the other hand, we will analyze several specific facts suggesting the non-descent of COVID_19 from Bat RaTG13.

3/ Evidence of the absence of 4 HIVISIV " Exogenous Informative Elements 》 from COVID_19 within SARS-2005 and MERS genomes.

The following Table 3, it appears that 14 of the 18 HIV SIV EIE existed - already - from the first human SARS genomes that appeared in China around 2003.

However, a novel long region of around 225 nucleotides, less than $1 \%$ of the genome, appears to us to have been inserted: this region is completely absent in ALL SARS genomes, whereas it is present and $100 \%$ homologous for all COVID-19 genomes listed in NCBI.

Table 4 - Comparing the 16 EIE from « $A$ », « $B$ » and remaining regions in COVID19, HIVISIV and SARS. 


\begin{tabular}{|c|c|c|c|c|c|}
\hline $\begin{array}{l}\text { HIV/SIV } \\
\text { «Exogenous } \\
\text { Informative } \\
\text { Elements » }\end{array}$ & $\begin{array}{l}\text { Locations within } \\
\text { «A } \| 600 \text { bases and } \\
\text { « } B » 330 \text { bases } \\
\text { regions }\end{array}$ & $\begin{array}{l}\text { Length nucleotides } \\
\text { in COVID_19 }\end{array}$ & $\begin{array}{l}\text { Length } \\
\text { nucleotides } \\
\text { in HIV-SIV EIE } \\
\% \text { HIV-SIV } \\
\text { / COVID_19 }\end{array}$ & $\begin{array}{l}\text { Len } \\
\text { in S } \\
\% \mathrm{~S}\end{array}$ & $\begin{array}{l}\text { gth nucleotides } \\
\text { ARS genomes } \\
\text { ARS/COVID_19 }\end{array}$ \\
\hline \multicolumn{6}{|c|}{ Region « $A$ » } \\
\hline HIV2 2012 France & $66-81$ & 16 unsignificant & $16100 \%$ & 13 & $81 \%$ \\
\hline HIV1 2017 Sweden & $154-174$ & 21 & $21100 \%$ & 19 & $90 \%$ \\
\hline HIV2 2012 Guinea & $236-253$ & 18 & $1794 \%$ & 11 & $61 \%$ \\
\hline SIV 2016 Africa & $366-386$ & 21 & $2095 \%$ & 18 & $86 \%$ \\
\hline \multicolumn{6}{|c|}{ Start 225bases zone including 4 « Exogenous Informative Elements » } \\
\hline HIV1 2008 Kenia & 471-501 & 32 & $88 \%$ & 0 & $0 \%$ \\
\hline $\begin{array}{l}\text { HIV2 } 2012 \text { Cap } \\
\text { verde }\end{array}$ & 512-529 & 18 & $18100 \%$ & 0 & $0 \%$ \\
\hline \multicolumn{6}{|c|}{ Region « B » } \\
\hline $\begin{array}{l}\text { HIV2 } 2014 \text { Cote } \\
\text { d'ivoire }\end{array}$ & $23-42$ & 20 & $1995 \%$ & 0 & $0 \%$ \\
\hline SIV 2016 Africa & 77-96 & 20 & $1995 \%$ & 0 & $0 \%$ \\
\hline \multicolumn{6}{|c|}{ End 225bases EIE zone including 4 « Exogenous Informative Elements » (note1) } \\
\hline $\begin{array}{l}\text { HIV1 } 2016 \\
\text { Netherlands } \\
\text { variant } \\
\text { HIV1 USA } 2011\end{array}$ & \begin{tabular}{|l|}
$85-112$ \\
$85-108$
\end{tabular} & 28 & $2589 \%$ & & $\begin{array}{l}46 \% \\
32 \%\end{array}$ \\
\hline $\begin{array}{l}\text { HIV2 } 1993 \text { côte } \\
\text { ivoire }\end{array}$ & $132-157$ & 26 & $2285 \%$ & 20 & $77 \%$ \\
\hline HIV2 2011 Sénégal & $179-194$ & 16 unsignificant & $16 \quad 100 \%$ & 12 & $75 \%$ \\
\hline HIV1 2013 Malawi & $212-243$ & 32 & $28 \quad 88 \%$ & 22 & $69 \%$ \\
\hline HIV1 2010 russia & $242-280$ & 39 & $32 \quad 82 \%$ & 15 & $38 \%$ \\
\hline $\begin{array}{l}\text { SIV } 2015 \\
\text { Cameroun. }\end{array}$ & $279-298$ & 30 & $25 \quad 83 \%$ & 10 & $33 \%$ \\
\hline \multicolumn{6}{|c|}{ others areas than the " $\mathrm{A}$ " and "B" regions } \\
\hline SIV 2015 Germany & $\begin{array}{l}8751 \\
8770 \\
\end{array}$ & 20 & $20100 \%$ & 9 & $45 \%$ \\
\hline HIV1 2016 China & $\begin{array}{l}14340 \\
14378 \\
\end{array}$ & 38 & $3387 \%$ & 34 & $89 \%$ \\
\hline HIV1 2004 USA & $\begin{array}{l}20373 \\
20401 \\
\end{array}$ & 28 & $2693 \%$ & 28 & $100 \%$ \\
\hline HIV1 2011 USA & $\begin{array}{l}20400 \\
20430\end{array}$ & 30 & $28 \quad 93 \%$ & 21 & $70 \%$ \\
\hline
\end{tabular}

Note1: these 2 genomes HIV1 2016 Netherlands variant and HIV1 USA 2011 are partially overlapping the $225 \mathrm{~b}$ region (85-112, 85-108), the 225b frontier is in relative region "B" adress 99.

Here we wanted to find out if the 16 EIE discovered in the COVID-19 genome already existed in the human SARS genomes that appeared in 2003.

Table 3 summarizes this research. In particular, it appears that 14 of the 18 HIV SIV EIE existed already - from the first human SARS genomes that appeared in China around 2003. 
However, a novel long region of around $\mathbf{2 2 5}$ nucleotides, apears to us to be totally new: this region is completely absent in ALL SARS genomes, whereas it is present and $100 \%$ homologous for all COVID-19 genomes listed in NCBI or GISAID COVID_19 genomic databases.

This region is located (in the COVID-19 genome which served as a reference) between the addresses 21550 and 21772. It is therefore located between the end of region "A" (475 to 600 bases locations) and the start of region "B" (1 to 99 bases locations).

A remarkable fact is also observed: the HIVISIV EIE which already existed in SARS have evolved a lot through numerous mutations. Thus, 4 EIE have very weak homologies (near 30\%) between their SARS version and their COVID-19 version. These homologies gradually improve in more recent SARS (2015 or 2017 for example, right column in Table 4).

The 4 « Exogenous Informative Elements » added in COVID_19 are respectively:

HIV1 Kenia 2008

HIV2 Cap verde 2012

HIV2 Ivory Coast 2014

SIV Africa 2016.

The reader will be able to note that these strains HIV1 HIV2 SIV are very recent and subsequent to the emergence of SARS. However, most of the other strains - which appear to us present in SARS - have dates after the emergence of the first SARS. This fact will have to be explained ...

The other case of MERS genome :

An analysis of the reference genome of the pathogenic RNA virus MERS ( Middle East respiratory syndrome coronavirus, complete genome NCBI Reference Sequence: NC_019843.3 , https://www.ncbi.nlm.nih.gov/nuccore/NC 019843.3?report=genbank ) shows that the end of our "A" region, all of the key 225 base regions, of the "B" region and of the "Lyonsweiler" region. 4 crucial regions of our article are totally ABSENT in MERS.

\section{4 - Evidence for HIVISIV sequences in this region and their compaction in 225 bases portion of both COVID_19 and Bat coronavirus RaTG13 genomes.}

We now analyze the level of homologies between the 4 strains HIVISIV of the 4 cases which are always present in COVID_19 but always absent in SARS.

The remarkable point is as follows: It is strange that the most significant "Bat" genome, Bat coronavirus RaTG13 genome [12], is from 2020, just like COVID_19 ... In particular, for the HIV1 Kenia 2008 sequence[9, 10], there remains the one and only strain found in the "Bat" population, while for the 3 other EIE, the "Bat" strains are very numerous but with non-significant HIV/SIV homologies.

Table 5 - Comparing the 4 EIE from COVID-19, HIVISIV and Bat coronavirus RaTG13 [12].

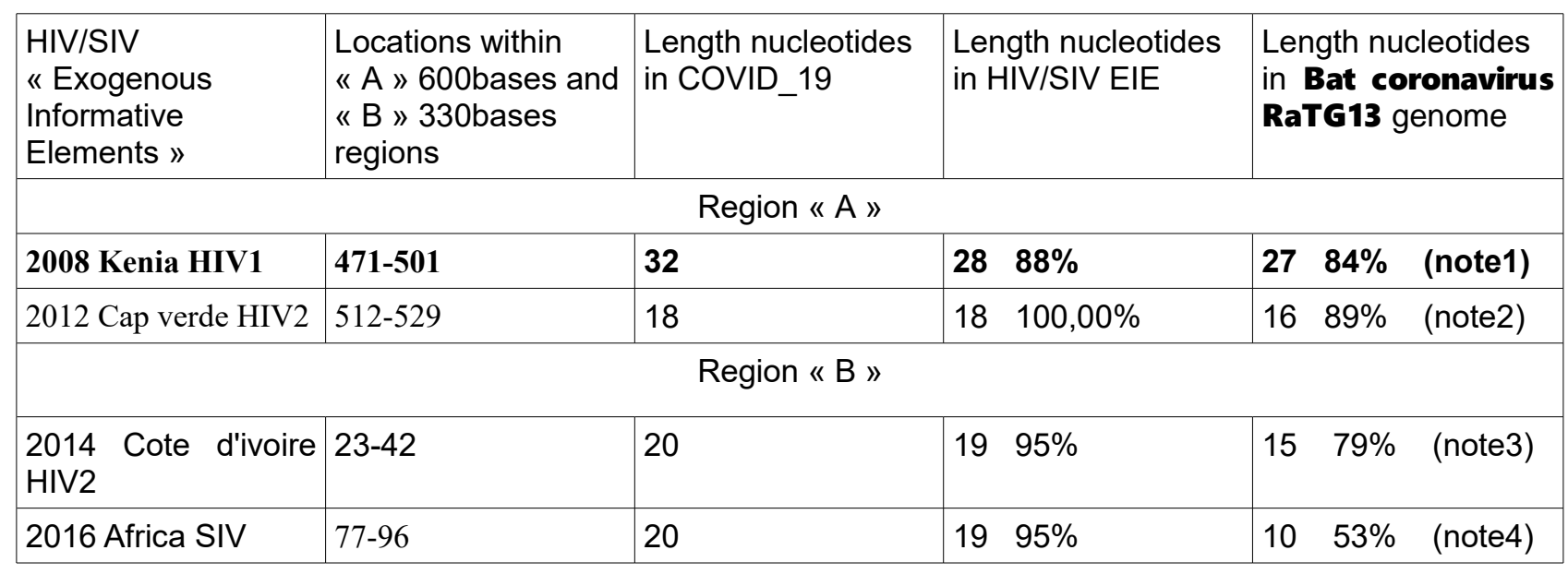

Note1 
COVID_19 / HIV1 28/32 88\%, Only both non COVID_19 strains:

Bat coronavirus RaTG13 and Rhinolophus affinis coronavirus isolate LYRa3 spike protein gene. No others Bat strains.

Note2

COVID 19 / HIV2 18/18 100\%, Bat. 16/18. 89\%, Sars urbani. 10/10

Various others Bat and sArs with VERY low homologies but all $<10$

Note3

COVID 19 / HIV2 19/20 95\%, Bat RaTG13. 15/17. 88\%. well. Sars urbani. 9/9

Various others Bat and sArs but all $<12$

Note4

COVID_19/SIV. 19/20. 95\%, Bat coronavirus RaTG13 Hiv, Bat. 10/10. Bad homology.

Various Bat and sArs all $<12$

Zooming on the first HIV1 Kenia Homologies :

Synthesis data : Comparing the 3 key regions « $A$ », " $B$ », and " Lyons-Weiler » region [4] in the cases of COVID-19, Bat RaTG13 coronavirus [12] and the best homologies for other Bat and SARS coronaviruses.

Table 6 - Comparing the 3 key regions « A », «B », and « Lyons-Weiler » region [4] in the cases of COVID-19, Bat RaTG13 coronavirus [12] and the best homologies for other Bat and SARS coronaviruses.

\begin{tabular}{|c|c|c|c|}
\hline Coronavirus genome & Region « $A$ » & Region « B » & Region « Lyons-weiler » \\
\hline COVID_19 & $600 / 600 \quad 100 \%$ & $330 / 330 \quad 100 \%$ & $1378 / 1378 \quad 100 \%$ \\
\hline Bat RaTG13 & $563 / 599 \quad 98 \%$ & $309 / 330$ & $1209 / 1311$ \\
\hline Other Bat & $518 / 60586 \%$ (note1a) & $75 \%$ (Note $1 \mathrm{~b})$ & $77 \%$ (Note1c) \\
\hline Other SARS & $400 / 47484 \%$ (note2a) & 144/177 $73 \%$ (Note 2b) & $79 \%$ (Note2c) \\
\hline
\end{tabular}

Note1a - Bat SARS-like coronavirus isolate bat-SL-CoVZC45

Note1b - BtRs-BetaCoV/YN2013, complete genome

Note 1C - Bat SARS-like coronavirus isolate bat-SL-CoVZC45, complete genome

Note2a - SARS coronavirus GZ0402, complete genome

Note $2 b$ - SARS coronavirus isolate CFB/SZ/94/03, complete genome

Note2c - SARS coronavirus SZ3, complete genome

5/ The determining case of HIV1 Kenya 2008 absent from all coronaviruses other than COVID_19 and RaTG13.

$==>==>$ Please see in Supplementary Materials (Ref 3) complete data on this particular EIE Kenya 2008. To summarize,

\section{The case of HIV1 Kenya 2008}

This important HIV1 genome was particularly studied in an HIV vaccine strategy context by Canadian Professor Franck Plummer Lab. Team [9, 10].

This region, in addition to its hundred strong homologies with all the COVID_19 strains of 2020, shows only 2 other homologies with, on the one hand, Bat coronavirus RaTG'13, and at a lower level, with Rhinolophus affinis coronavirus isolate LYRa3 spike protein gene.

The HIV1 Kenya 2008 fingerprint recall :

TGTTTTTATTACTTTTATTGCCACTATTCTCT

Here is the detail of these 2 main homologies: 
Severe acute respiratory syndrome coronavirus 2 isolate Wuhan-Hu-1, complete genome Sequence ID: NC 045512.2Length: 29903Number of Matches: 1

\begin{tabular}{|c|c|c|c|c|}
\hline Score & Expect Identities & Gaps & Strand & \\
\hline 37.4 bits $(40)$ & $8 e-04 \quad 28 / 32(88 \%)$ & $1 / 32(3 \%)$ & Plus/Plus & \\
\hline Query 1 & $\begin{array}{c}\text { TGTTTTTATTACTT } \\
|||||||| \mid\end{array}$ & TATTGCCAC & $\begin{array}{l}\text { CTATTCTCT } \\
||||||||||\end{array}$ & 32 \\
\hline 21568 & TGTTTTTCTTG-TT & TATTGCCAC & СТАGTCTCT & $2159 \varepsilon$ \\
\hline
\end{tabular}

Bat coronavirus RaTG13, complete genome

Sequence ID: MN996532.1Length: 29855Number of Matches: 1

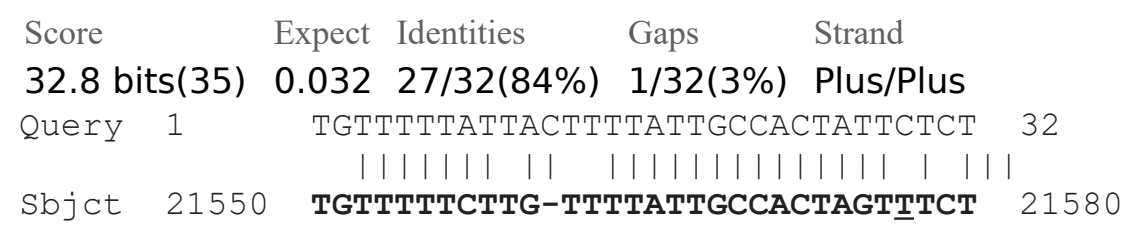

==> ==> Please, see the detailed Table2.1 in Supplementary Materials Ref 4 ( Dates of collection then deposit of various Bat genomes involved in the 225 bases region ) .

This Table results from the BLASTn analysis on April 10, 2020 option "SARS coronaviruses taxid 694009" reports 386 occurrences including 16 bats and 2 Rhinolophus, and 368 COVID_19.

In this Table, we demonstrate that ALL Bats genomes others than Bat RaTG $\overline{1} 3$ none of them have the presence of the EIE Kenya 2008.

In ALL cases, the 225bases region is reduced to contiguous small regions between 17 and 96 bases length. In ALL cases, the Kenya 2008 EIE is totally absent.

We also note in this Table that the Bats closest to COVID_19 were collected between 2013 and 2017, but only sequenced in 2020 (BatRaTG13 (2013), B at SARS-like coronavirus isolate bat-SL-CoVZXC21 (2015), and Bat SARS-like coronavirus isolate bat-SL-CoVZC45 (2017).

\section{Location of the EIE HIV1 Kenya 2008 against the Spike gene:}

Firstly, the EIE regions of HIV1 Kenya 2008 nonfunctional ( Sequence ID: EU875177.1 ) and of HIV1 Kenya real ( Sequence ID: FJ623481.1 ) are identical while the respective Gp120 genes are only 82\% homologous: 494/603 (82\%) .

HIV-1 isolate 06KECst_005 from Kenya, complete genome

Sequence ID: FJ623481.1Length: 8766Number of Matches: 1

Range 1: 5192 to 5794

$\begin{array}{lllll}\text { Score } & \text { Expect } & \text { Identities } & \text { Gaps } & \text { Strand } \\ 595 \text { bits(659) } & 6 e-168 & 494 / 603(82 \%) & 3 / 603(0 \%) & \text { Plus/Plus }\end{array}$

In other hand, The HIV1 Kenya EIE nonfunctional region from COVID_19 genome is located overlapping between the end of the "orf1ab" gene and the start of the "S spike" gene :

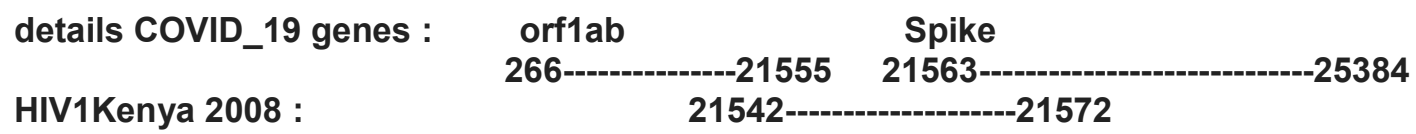

COVID_19 Wuhan market ID: LR757998.1 reference genome location of EIE Kenya 2008 HIV1 : 21542-21572 bases.

Spike gene location: 21563-25384 bases.

So, in terms of amino acids:

START address of HIV1 KENYA: 21 amino acids before SPIKE begins. 
END address of HIV1 KENYA: 9 amino acids after the beginning of SPIKE.

Finally, how is this same question in the case of bat RaTG13 genome?

Locations of HIV1 Kenya within Bat RaTG13 Sequence ID: MN996532.1

is: 21550 TGTTTTTCTTG-TTTTATTGCCACTAGTTTCT 21580

(see RESULTSS ref 3 ).

Location of Spike gene within BatRaTG13 is: 21545..25354

/gene="S"

/ codon start $=1$

/product="spike glycoprotein"

/protein_id="QHR63300.2"

So, in terms of amino acids:

START address of HIV1 KENYA: 6 amino acids after SPIKE begins.

END address of HIV1 KENYA: 36 amino acids after the beginning of SPIKE.

So, unlike COVID_19 where HIV1 Kenya starts before the start of the SPIKE gene, here, in the case of bat RaTG13, HIV1 Kenya is entirely contained within the SPIKE gene.

\section{6- The discovery of a new EIE from the HIV1 group « $O$ » differentiating COVID_19 and Bat RaTG13 genomes.}

HIV1 group « $\mathrm{O}$ » constitutes a subgroup of HIV retroviruses very different comparing with others HIV/SIV subgroups, it appears particularly in Cameroon. However, little is known about group $\mathrm{O}$ and why this highly divergent retrovirus genome has not become pandemic [21].

We wanted to look for hypothetical traces of EIE coming from HIV group "O", more particularly, we looked for possible traces in COVID_19 and in bat RaTG13.

We then discover a POL (Integrase) homology from this strain HIV1 group "O", referenced AF422215.1, it is located towards the 23800 bases of COVID_19.

$==>$ On April 21, 2020, BLASTn reported 489 COVID_19 sequences - all the sequences available on this date - with ALL of the following homology: 20/22 (90.91\%), excepted 2 high level deleted strains reported below.

$==>$ As of May 4, 2020, BLASTn is providing 1578 COVID_19 sequences. All except 3 highly deleted at whole genome scale ( Severe acute respiratory syndrome coronavirus 2 isolate SARS-CoV-

2/human/USA/CA-CZB-IX00017/2020, ID: MT385497.1

, Severe acute respiratory syndrome coronavirus 2 isolate SARS-CoV-2/human/USA/UT-00087/2020,

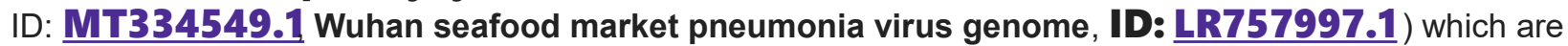
very highly deleted contain this sequence completely preserved according to its homology of 20/22 bases, ie $90.91 \%$ of homology.

We must recall here this homology :

Between HIV-1 strain group $O$ isolate 98CMA010 from Cameroon integrase (pol) gene, partial cds

GenBank: AF422215.1 https://www.ncbi.nlm.nih.gov/nuccore/AF422215.1

and

Wuhan seafood market pneumonia virus genome assembly, chromosome: whole_genome

Sequence ID: LR757998.1Length: 29866Number of Matches: 1

Range 1: 23804 to 23825

\begin{tabular}{|c|c|c|c|}
\hline Score & $\begin{array}{l}\text { Expec } \\
t\end{array}$ & Gaps & Strand \\
\hline $31.9 \operatorname{bits}(34)$ & $3.0 \quad 20 / 22(91 \%)$ & $0 / 22(0 \%)$ & Plus/Plus \\
\hline Query 532 & $\begin{array}{c}\text { ATGGCAGTATTTG } \\
|||||||| \mid)\end{array}$ & $\begin{array}{l}\text { TCACAAT } \\
||||||\end{array}$ & 553 \\
\hline
\end{tabular}


The same research applied to Bat RaTG13 ID: MN996532.1 produces the results summarized by the Synthesis below:

\section{Synthesis :}

HIV1 Group O 532 ATGGCAGTATTTGTTCACAATT 553

COVID_19 23804 ATGGCAGTTTTTGTACACAATT 23825

bat RaTG13 23799 ATGGTAGTTTTTGCACACAATT 23820

differences $\quad \mathrm{X} \quad \mathrm{X} \quad$ between COVID_19 and HIV1 gr O

differences $\quad \mathrm{X} \quad \mathrm{X} \quad$ between COVID_19 and bat RaTG13

differences $\quad \mathrm{X} \quad \mathrm{X} \quad \mathrm{XX} \quad$ between batRaTG13 and HIV1 gr O

$(18 / 22)$

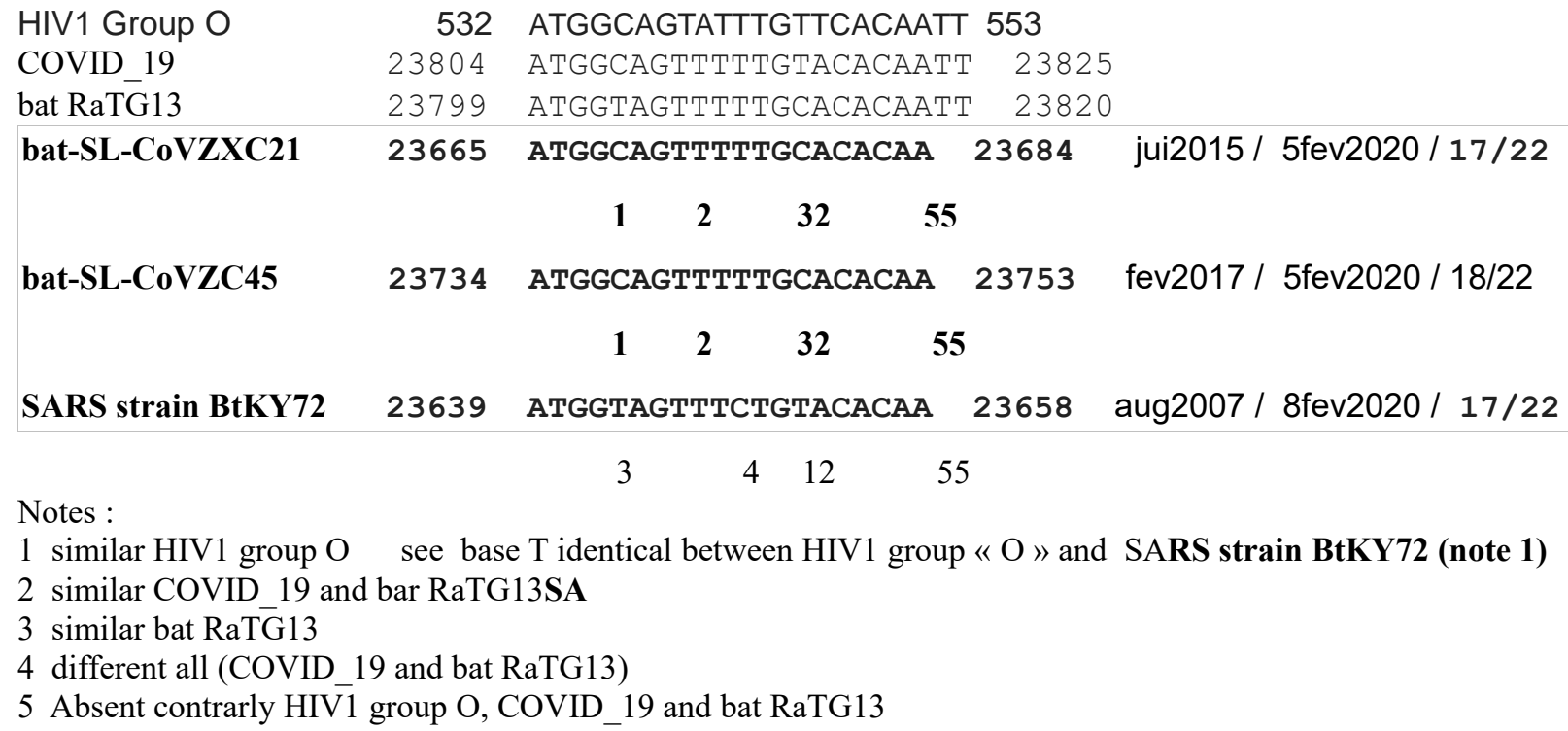

a/ It is well known that bats have been studied in particular in China in recent years ( https://en.wikipedia.org/wiki/Shi Zhengli ).

b/ The respective collection dates of these Bat genomes are 2007, 2013, 2015, 2017 while all of them were only sequenced in 2020 (with the exception of BtRf-BetaCoV / HeB2013, sequenced in 2017).

c/ We observe that all these Bat SARS strains have COVID_19 homologies in this region quite close to that of Bat RaTG13.

d/ It is remarkable to note (note1) this base T which is the only one to be simultaneously present in HIV1 group "O" and in SARS strain BtKY72.

e/ Finally, while COVID_19 has a homology of 20/22 bases with HIV1 group "O", Bat RaTG13 (2013) and bat-SL-CoVZC45 (2017) have a homology of 18/22 bases with HIV1 group "O".

\section{7- Analysis of local and global cohesions and heterogeneities of the 225bases COVID_19, bat RaTG13 and SARS Urbani genomes.}

Now, we demonstrate how and why a new region including 4 HIVISIV EIE radically distinguishes all COVID19 strains from all SARS and Bat strains.

Then, we will be particularly interested in the Bat RaTG13 strain whose genomic proximity to COVID-19 will be analyzed with the greatest attention and precision.

The theoretical method used here makes it possible to evaluate the overall level of cohesion - then also of heterogeneity - of a sequence of nucleotides, and that whatever the scale due to the fractal nature of this numerical method. 
Full details on the "DNA Master Code" numerical method are summarized in supplementary Materials.

Here we analyze the Master Code of 3 characteristic genomes COVID_19, bat RaTG13 and SARS Urbani.

We will study, for each of these 3 genomes, 5 successive amplitude scales and this according to the 3 reading frames of the codins and on the 2 main and complementary strands:

- whole genomes.

- bases 15,000 to 25,000 .

-region including "A", "B", "lyons weiler".

- regions of 425 bases including 100, 225, 100 bases.

- 225 bases area.

Full deoails are available in Supplementary Materials2 «I $\mid$.

Table 7 - Synthetic Genomics/Proteomic global Master Code coupling (\%). Nota : we select in each case the best codons reading frame \% coupling.

\begin{tabular}{|l|l|}
\hline Genome & Selective Region 225 bases \\
\hline Wuhan market ID: $\underline{\text { LR757998.1 }}$ & $\underline{\mathbf{6 9 . 4 7}}$ \\
\hline BatRaTG13 ID: $\underline{\text { MN996532.1 }}$ & $\underline{\mathbf{9 2 . 1 3}}$ \\
\hline SARS Urbani ID: $\underline{\text { MK062180.1 }}$ & Absent \\
\hline
\end{tabular}

The main result to be discussed now is the comparison between both 225 bases region analyses of COVID_19 and BatRaTG13 (Bold in the Table 13).

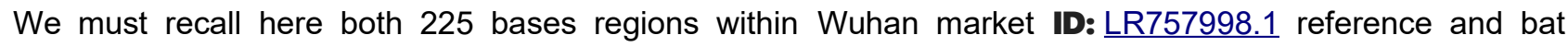
RaTG13 genomes :

Wuhan seafood market pneumonia virus genome assembly, chromosome: whole_genome

Sequence ID: LR757998.1Length: 29866Number of Matches: 1

Score Expect Identities Gaps Strand

407 bits(450) $\quad 7 e-114 \quad 225 / 225(100 \%) \quad 0 / 225(0 \%) \quad$ Plus/Plus

Bat coronavirus RaTG13, complete genome

Sequence ID: MN996532.1Length: 29855Number of Matches: 1

\begin{tabular}{|c|c|c|c|c|}
\hline Score & Expect & Identities & Gaps & Strand \\
\hline 312 bits(345) & $4 \mathrm{e}-85$ & $204 / 225(91 \%)$ & $0 / 225(0 \%)$ & \\
\hline
\end{tabular}

The sequence SARS Urbani is totally absent selecting 1000 SARS like genomes in BLAST..

Homology of the 225 bases region between Wuhan market ID: $\underline{\text { R757998.1 }}$ ref. and bat RaTG13 is very important : $204 / 225$ bases (91\% homology).

Analysing the locations of the 4 HIV1 HIV2 EIE within the 225 bases region :

Wuhan market ID: LR757998.1 start adress : 21543. Bat start adress : 21550.

Nucleotides and amino acids within Wuhan market ID: ㄴR757998.1 225 bases region :

HIV1 Kenya 2008

471501 Nucleotides adresses within region « $A$ ॥ 600 bases

$131 \quad$ Nucleotides adresses within region 225 bases 
HIV2 Cap verde 2012

512529 Nucleotides adresses within region « $A$ » 600 bases

42. 59 Nucleotides adresses within region 225 bases

14. 20 Amino acids within region 225 bases

HIV2 Cote d' ivoire 2014

6685 Nucleotides adresses within region « B » 330 bases

195. 214. Nucleotides adresses within region 225 bases

65. 71 Amino acids within region 225 bases

SIV Africa 2016

7697 Nucleotides adresses within region « B » 330 bases

205. 226 Nucleotides adresses within region 225 bases

68. 75 Amino acids within region 225 bases

Homologies between BatRaTG13[21549 on 225 bases] =Wuhan market ID: LR757998.1 ref [21542 on 225 bases]

\begin{tabular}{|c|}
\hline 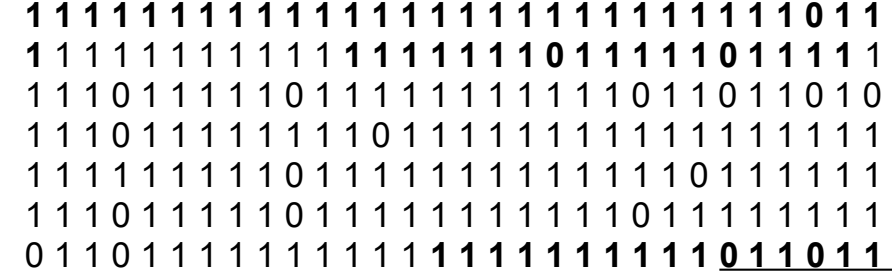 \\
\hline \\
\hline
\end{tabular}

111111111110111

Kenya HIV1

Cap verde HIV2

2 last HIV2 and SIV have a partial overlap.

Then, only 20 bases differences on 225 bases.

Nota : The regions in bold correspond to the relative positions of the 4 EIEs HIV1 Kenya 2008, HIV2 Cape Verde 2012, HIV2 Cote d (ivoire 2014 and SIV Africa 2016.

Wuhan market ID: LR757998.1 ref region 225 basesFrame1

TGTTTTTCTTGTTTTATTGCCACTAGTCTC

TAGTCAGTGTGTTAATCTTACAACCAGAAC TCAATTACCCCCTGCATACACTAATTCTTT CACACGTGGTGTTTATTACCCTGACAAAGT TTTCAGATCCTCAGTTTTACATTCAACTCA GGACTTGTTCTTACCTTTCTTTTCCAATGT TACTTGGTTCCATGCTATACATGTCTCTGG GACCAATGGTACTAA

bat RaTG13 region 225 bases

Frame1

TGTTTTTCTTGTTTTATTGCCACTAGTTTC

TAGTCAGTGTGTTAATCTAACAACTAGAAC TCAGTTACCTCCTGCATACACCAACTCATC CACCCGTGGTGTCTATTACCCTGACAAAGT TTTCAGATCTTCAGTTTTACATTTAACTCA GGATTTGTTTTTACCTTTCTTCTCCAATGT GACCTGGTTCCATGCTATACATGTTTCAGG GACCAATGGTATTAA

Wuhan market ID: LR757998.1 region 225 bases FRAME1

CYS PHE SER CYS PHE ILE ALA THR SER LEU ARR SER VAL CYS ARR SER TYR ASN GLN ASN SER ILE THR PRO CYS ILE HIS ARR PHE PHE HIS THR TRP CYS LEU LEU PRO ARR GLN SER PHE GLN ILE LEU SER PHE THR PHE ASN SER GLY LEU VAL LEU THR PHE LEU PHE GLN CYS TYR LEU VAL PRO CYS TYR THR CYS LEU TRP ASP GLN TRP TYR ARR
Kenya HIV1

Cap verde HIV2

2 last HIV1 and SIV have a partial overlap 
bat RaTG13 region 225 bases

FRAME1

CYS PHE SER CYS PHE ILE ALA THR SER PHE ARR SER VAL CYS ARR SER ASN ASN ARR ASN SER VAL THR SER CYS ILE HIS GLN LEU ILE HIS PRO TRP CYS LEU LEU PRO ARR GLN SER PHE GLN ILE PHE SER PHE THR PHE ASN SER GLY PHE VAL PHE THR PHE LEU LEU GLN CYS ASP LEU VAL PRO CYS TYR THR CYS PHE ARG ASP GLN TRP TYR ARR

Kenya HIV1

Cap verde HIV2

2 last HIV1 and SIV have a partial overlap

Nota : The best nucleotides and amino acids matchings must be analyzed from the 3 codons and directions of codons reading frames.

In other words, in this above Table5 we see that apart from HIV1 KENYA the HIVs of the 225 bases region are more homologous in Wuhan market ID: LR757998.1 than in batRATG13.

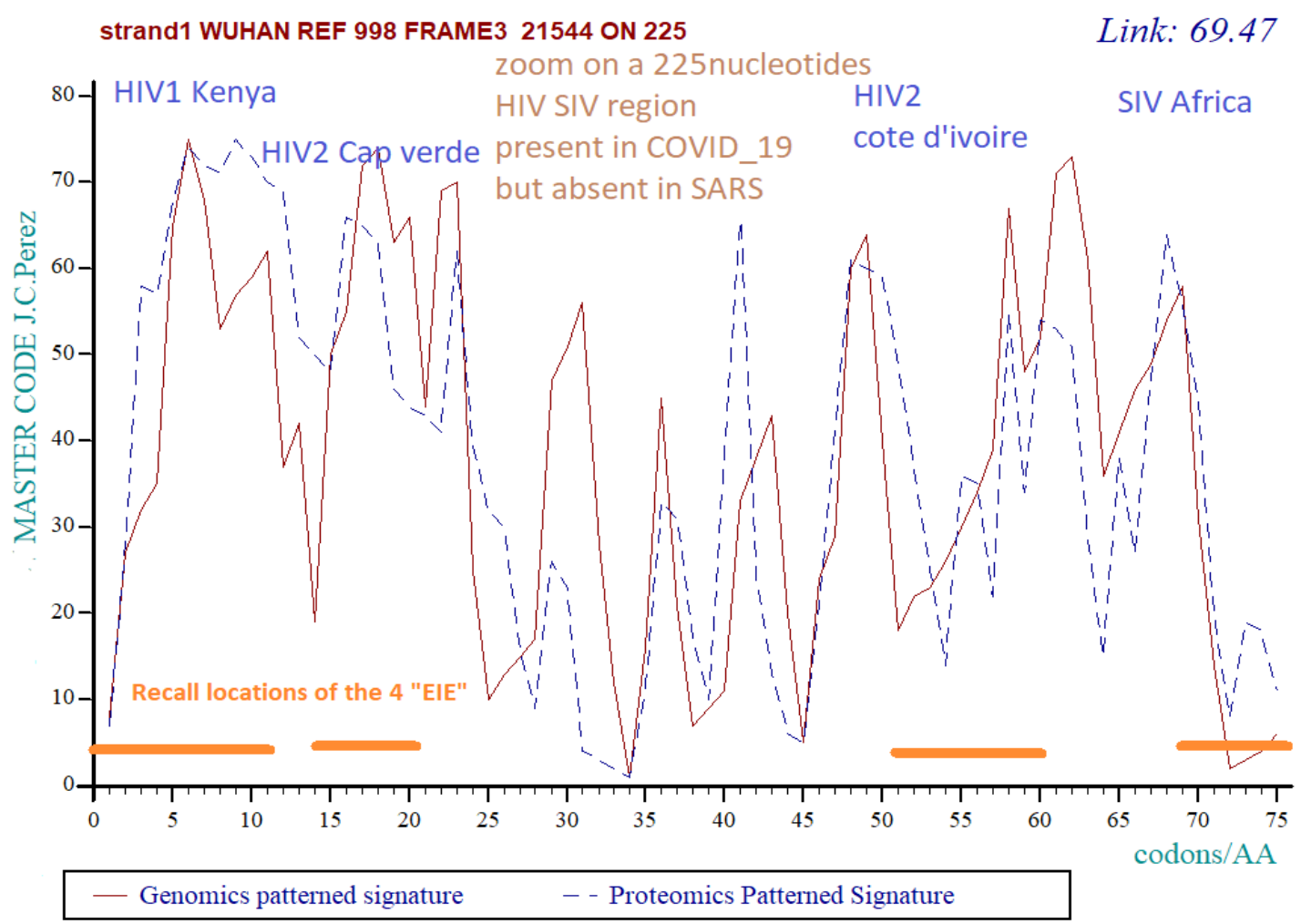

Figure 4 - High level of HETEROGENEITY within the 225 bases region in Wuhan market ID: LR757998.1 reference genome. 


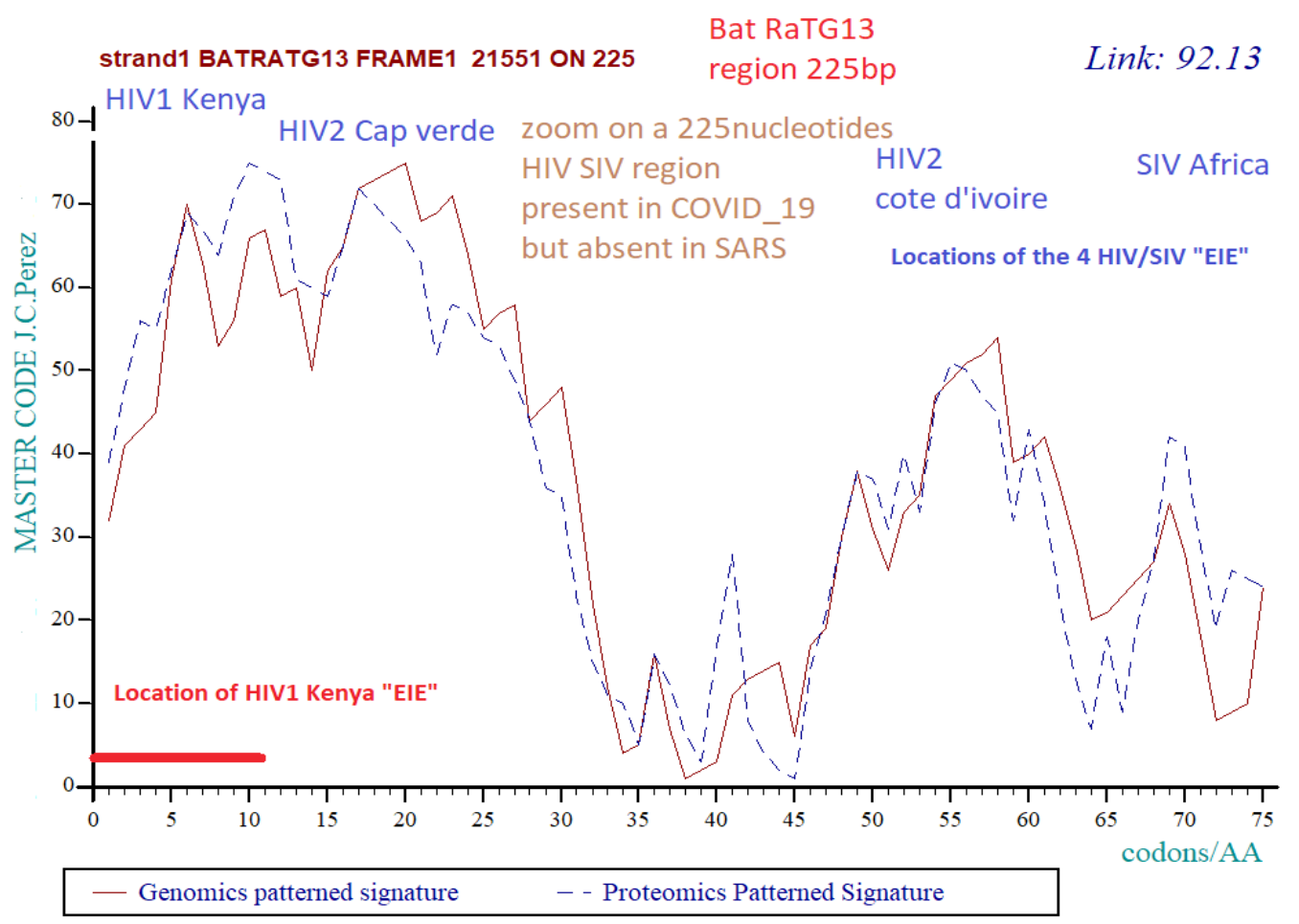

Figure 5 - High level of COHESION in 225 bases bat RaTG13 region including the fingerprint of Kenya HIV1 but not the 3 others HIV SIV signatures.

We will draw the reader's attention to the 2 figures 8 and 9 above: The first concerns the 225b region of COVID-19 (Fig. 8), it appears chaotic and not very organized. On the contrary, the same analysis for the same 225bases region in bat RaTG13 (Fig. 9) shows a more "smoothed" and regular profile. Let us not forget that this sequence, although filed in 2020, was taken in 2013,then 7 years earlier.

\section{Part III/III}

\section{In the decreasing slope of the epidemic, this 225 bases region exhibits an abnormally high rate of mutations/deletions, particularly in USA WA state (Seattle).}

\section{8- First encouraging mutations in the 225 bases, « $A$ » and « $B$ ॥ regions, particularly in USA WA state.}

We must recall here that the BLASTn analysis on April 10, 2020 option "SARS coronaviruses" reports 386 occurrences including 16 bats, 2 Rhinolophus, and 368 COVID_19. The same research running on 16 april 2020 reveals 523 strains sequences. The number of COVID_19 sequences available is therefore constantly changing principally due to USA new sequences deposits.

We were interested in the first cases of significant COVID_19 mutations in this key region of 225 bases (homologies of the order of $96 \%$ ). we find 5 of them located in the BLASTn just in front of and near RaTG13, all come from the USA, taken and sequenced in April 2020, pathogenic.

A BLASTn analysis dated April 11, 2020 produces the following results:

386 sequences in total. whose:

351 strains with full 100\% homology with 225 bases region.

17 strains with mutations in 225 bases region.

18 strains bat.

Now let's look at these 17 cases of mutations in the 220 bases region. 
Table 8 - Mutations in region 225 bases

\begin{tabular}{|c|c|c|c|c|c|}
\hline $\begin{array}{l}\text { Strain } \\
\text { number }\end{array}$ & Strain reference & $\begin{array}{l}\text { Mutations } \\
\text { relatives } \\
\text { adresses } \\
\text { within } 225 \\
\text { bases } \\
\text { region }\end{array}$ & Homologies & $\begin{array}{l}\text { HIV1/SIV } \\
\text { EIE } \\
\text { note1 }\end{array}$ & $\begin{array}{l}\text { Collection and } \\
\text { deposit dates }\end{array}$ \\
\hline 1 USA & $\begin{array}{l}\text { SARS-CoV-2/WA-UW381/human/2020/USA, } \\
\text { partial genome Sequence ID: } \underline{\text { MT263460.1 }}\end{array}$ & $\begin{array}{l}8 \\
C / T\end{array}$ & $\begin{array}{l}224 / 225 \\
99.6 \%\end{array}$ & $\begin{array}{l}\text { HIV1 } \\
\text { Kenya } \\
2008\end{array}$ & $\begin{array}{l}30 \text { mar } 2020 \\
6 \text { apr } 2020\end{array}$ \\
\hline 2 USA & $\begin{array}{l}\text { SARS-CoV-2/WA- } \\
\text { UW334/human/2020/USA, complete } \\
\text { genome Sequence ID: MT263414.1 }\end{array}$ & 8 & $\begin{array}{l}224 / 225 \\
99.6 \%\end{array}$ & $\begin{array}{l}\text { HIV1 } \\
\text { Kenya } \\
2008\end{array}$ & $\begin{array}{l}24 \text { mar } 2020 \\
06 \text { apr } 2020\end{array}$ \\
\hline 3 USA & $\begin{array}{l}\text { ARS-CoV-2/WA- } \\
\text { UW301/human/2020/USA, complete } \\
\text { genome Sequence ID: MT263384.1 }\end{array}$ & $\begin{array}{l}81 \\
C / T\end{array}$ & $\begin{array}{l}224 / 225 \\
99.6 \%\end{array}$ & & $\begin{array}{l}23 \text { mar } 2020 \\
06 \text { apr } 2020\end{array}$ \\
\hline 4 USA & $\begin{array}{l}\text { SARS-CoV-2/WA- } \\
\text { UW270/human/2020/USA, partial } \\
\text { genome } \\
\text { Sequence ID: MT259262.1 }\end{array}$ & $\begin{array}{l}79 \\
\mathrm{C} / \mathrm{T}\end{array}$ & $\begin{array}{l}224 / 225 \\
99.6 \%\end{array}$ & & $\begin{array}{l}13 \text { mar } 2020 \\
06 \text { apr } 2020\end{array}$ \\
\hline 5 USA & $\begin{array}{l}\text { SARS-CoV-2/WA- } \\
\text { UW257/human/2020/USA, complete } \\
\text { genome Sequence ID: MT259249.1 }\end{array}$ & $157 \mathrm{G} / \mathrm{C}$ & $\begin{array}{l}224 / 225 \\
99.6 \%\end{array}$ & & $\begin{array}{l}13 \text { mar } 2020 \\
6 \text { apr } 2020\end{array}$ \\
\hline 6 USA & $\begin{array}{l}\text { SARS-CoV-2/WA- } \\
\text { UW231/human/2020/USA, complete } \\
\text { genome Sequence ID: MT246488.1 }\end{array}$ & $\mathrm{C} / \mathrm{T}$ & $\begin{array}{l}224 / 225 \\
99.6 \%\end{array}$ & $\begin{array}{l}\text { HIV1 } \\
\text { kenya } \\
2008\end{array}$ & $\begin{array}{l}14 \text { mar } 2020 \\
06 \text { apr } 2020\end{array}$ \\
\hline 7 USA & $\begin{array}{l}\text { SARS-CoV-2/WA- } \\
\text { UW204/human/2020/USA, complete } \\
\text { genome Sequence ID: MT246461.1 } \\
\end{array}$ & $\mathrm{C} / \mathrm{T}$ & $\begin{array}{l}224 / 225 \\
99.6 \%\end{array}$ & $\begin{array}{l}\text { HIV1 } \\
\text { kenya } \\
2008\end{array}$ & $\begin{array}{l}13 \text { mar } 2020 \\
06 \text { apr } 2020\end{array}$ \\
\hline 8 China & $\begin{array}{l}\text { SARS-CoV-2/KMS1/human/2020/CHN, } \\
\text { complete genome } \\
\text { Sequence ID: MT226610.1 }\end{array}$ & 217 T/A & $\begin{array}{l}224 / 225 \\
99.6 \%\end{array}$ & $\begin{array}{l}\text { SIV Africa } \\
2016\end{array}$ & $\begin{array}{l}20 \text { jan } 2020 \\
06 \text { apr } 2020\end{array}$ \\
\hline 9 Finland & $\begin{array}{l}\text { CoV-FIN-29-Jan-2020, partial genome } \\
\text { Sequence ID: MT020781.2 }\end{array}$ & $140 \mathrm{C} / \mathrm{T}$ & $\begin{array}{l}224 / 225 \\
99.6 \%\end{array}$ & & $\begin{array}{l}29 \text { jan } 2020 \\
17 \text { mar } 2020\end{array}$ \\
\hline $\begin{array}{l}10 \\
\text { China }\end{array}$ & $\begin{array}{l}\text { SARS-CoV-2/Yunnan- } \\
\text { 01/human/2020/CHN, complete genome } \\
\text { Sequence ID: MT049951.1 }\end{array}$ & $\begin{array}{l}77 \\
\text { T/A }\end{array}$ & $\begin{array}{l}224 / 225 \\
99.6 \%\end{array}$ & & $\begin{array}{l}17 \text { jan } 2020 \\
06 \text { apr } 2020\end{array}$ \\
\hline $\begin{array}{l}11 \\
\text { USA }\end{array}$ & $\begin{array}{l}\text { 2019-nCoV/USA-CA5/2020, complete } \\
\text { genome } \\
\text { Sequence ID: MT027064.1 }\end{array}$ & $140 \mathrm{C} / \mathrm{T}$ & $\begin{array}{l}224 / 225 \\
99.6 \%\end{array}$ & & $\begin{array}{l}24 \text { mar } 2020 \\
06 \text { apr } 2020\end{array}$ \\
\hline 12 USA & $\begin{array}{l}\text { SARS-CoV-2/WA- } \\
\text { UW302/human/2020/USA, partial } \\
\text { genome Sequence ID: MT263385.1 }\end{array}$ & $\begin{array}{l}175-176 \\
\text { CA/NN } \\
164-166 \\
\text { CCT/NNN }\end{array}$ & $\begin{array}{l}220 / 225 \\
97.7 \%\end{array}$ & & $\begin{array}{l}23 \text { mar } 2020 \\
6 \text { apr } 2020\end{array}$ \\
\hline 13 USA & $\begin{array}{l}\text { SARS-CoV-2/WA- } \\
\text { UW356/human/2020/USA, complete } \\
\text { genome Sequence ID: MT263436.1 }\end{array}$ & $\begin{array}{l}\text { 188-196 } \\
\text { TTCCATGC } \\
\text { T/NNNNNN } \\
\text { NNN }\end{array}$ & $\begin{array}{l}216 / 225 \\
96 \%\end{array}$ & $\begin{array}{l}\text { HIV2 cote } \\
\text { d'ivoire } \\
2014\end{array}$ & $\begin{array}{l}24 \text { mar } 2020 \\
06 \text { apr } 2020\end{array}$ \\
\hline 14 USA & $\begin{array}{l}\text { SARS-CoV-2/WA- } \\
\text { UW351/human/2020/USA, complete } \\
\text { genome Sequence ID: } \underline{\text { MT263431.1 }}\end{array}$ & $\begin{array}{l}189-197 \\
\text { TTCCATGCT } \\
\text { A/NNNNNN } \\
\text { NNN }\end{array}$ & $\begin{array}{l}216 / 225 \\
96 \%\end{array}$ & $\begin{array}{l}\text { HIV2 cote } \\
\text { d'ivoire } \\
2014\end{array}$ & $\begin{array}{l}24 \text { mar } 2020 \\
06 \text { apr } 2020\end{array}$ \\
\hline
\end{tabular}




\begin{tabular}{|l|l|l|l|l|l|}
\hline 15 USA & $\begin{array}{l}\text { SARS-CoV-2/WA- } \\
\text { UW287/human/2020/USA, complete } \\
\text { genome Sequence ID: MT259277.1 }\end{array}$ & $\begin{array}{l}189-197 \\
\text { TCCATGCT } \\
\text { A/NNNNNN } \\
\text { NNN }\end{array}$ & $\begin{array}{l}216 / 225 \\
96 \%\end{array}$ & $\begin{array}{l}\text { HIV2 cote } \\
\text { d'ivoire } \\
2014\end{array}$ & $\begin{array}{l}15 \text { mar } 2020 \\
06 \text { apr } 2020\end{array}$ \\
\hline 16 USA & $\begin{array}{l}\text { SARS-CoV-2/WA- } \\
\text { UW306/human/2020/USA, partial } \\
\text { genome Sequence ID: MT263389.1 }\end{array}$ & $\begin{array}{l}145-191 \\
46 \text { del }\end{array}$ & $\begin{array}{l}144 / 144 \\
100 \% \\
\text { then 34/34 }\end{array}$ & $\begin{array}{l}23 \text { mar } 2020 \\
06 \text { apr } 2020\end{array}$ \\
\hline 17 China & $\begin{array}{l}\text { Wuhan seafood market pneumonia virus } \\
\text { genome assembly, chromosome: } \\
\text { whole_genome } \\
\text { Sequence ID: LR757997.1 }\end{array}$ & $\begin{array}{l}106-225 \\
120 \text { del }\end{array}$ & $\begin{array}{l}1-105 \\
100 \%\end{array}$ & $\begin{array}{l}\text { HIV2 } \\
\text { cote } \\
\text { d'ivoire } \\
2014 \\
\text { and SIV } \\
\text { Africa } \\
2016\end{array}$ & $\begin{array}{l}31 \text { dec } 2019 \\
\text { mar } 20209\end{array}$ \\
\hline
\end{tabular}

Note1 : when the mutation is in HIV/SIV insert, we note the strain ref.

We observe that out of these 17 cases of mutations, the majority of them (13/17) concern the USA with dates posterior to the Chinese origin of the pandemic. Only 3 relate to China and one to Finland. There is probably the beginning if a mutations strategy of the genome to balance and integrate exogenous HIV EIE.

On the other hand 9 of these 17 mutations directly affect an HIV / SIV region. The others affect the intermediate region separating the 2 and 2 HIV / SIV pools.

Thirdly, there are also deletions of whole EIE which is characteristic of RNA viruses.

It will also be noted that the majority of these strains come from recent samples (12/17 have dates of collection posterior or equal to March 2020). These dates would therefore correspond to a "mature" period of the COVID_19 genomes, which have now entered a phase of diversified mutations.

Finally, we observe the repetition of several mutations, proof of a robust mutations strategy process which eliminates the hypothesis of sequencing errors.

We note that 5 different HIV/SIV EIE and 5 mutations regions are matching within the 17 different COVID_19 strains.

Now we consider Table 9 - Comparing 225b region significative mutations $§$ deletions \% with whole genomes mutations and deletions \%.

Table 9 - Comparing $225 \mathrm{~b}$ region significative mutations $§$ deletions \% with whole genomes mutations and deletions \%.

\begin{tabular}{|c|c|c|c|c|c|c|}
\hline $\begin{array}{l}\text { Strain } \\
\text { number }\end{array}$ & Strain reference & $\begin{array}{l}\text { Mutations } \\
\text { relatives } \\
\text { adresses } \\
\text { within } 225 \\
\text { bases } \\
\text { region }\end{array}$ & $\begin{array}{l}\text { Homologies } \\
\text { region 225b / } \\
\text { same region in } \\
\text { reference } \\
\text { genome } \\
\text { LR757998.1 } \\
\text { and mutations } \\
\text { rate \% }\end{array}$ & $\begin{array}{l}\text { Homologies } \\
\text { whole genomes } \\
\text { / } \\
\text { whole } \\
\text { reference } \\
\text { genome } \\
\text { LR757998.1 } \\
\text { and mutations } \\
\text { rate \% }\end{array}$ & $\begin{array}{l}\text { HIV1/S } \\
\text { IV } \\
\text { EIE } \\
\\
\\
\end{array}$ & $\begin{array}{l}\text { Collection } \\
\text { and } \\
\text { deposit } \\
\text { dates }\end{array}$ \\
\hline 12 USA & $\begin{array}{l}\text { SARS-CoV-2/WA- } \\
\text { UW302/human/2020/USA, } \\
\text { partial genome Sequence } \\
\text { ID: MT263385.1 }\end{array}$ & $\begin{array}{l}175-176 \\
\text { CA/NN } \\
164-166 \\
\text { CCT/NNN }\end{array}$ & $\begin{array}{l}220 / 225 \\
\mathbf{9 7 . 7} \% \\
\mathbf{2 . 2 2 2 2 2 2} \%\end{array}$ & $\begin{array}{l}29517 / 29598 \\
=81 \\
99.726333 \% \\
0.273667 \%\end{array}$ & & $\begin{array}{l}23 \text { mar } \\
2020 \\
6 \text { apr } 2020\end{array}$ \\
\hline 13 USA & $\begin{array}{l}\text { SARS-CoV-2/WA- } \\
\text { UW356/human/2020/USA, } \\
\text { complete genome Sequence }\end{array}$ & $\begin{array}{l}\text { 188-196 } \\
\text { TTCCATGC } \\
\text { T/ } \\
\text { NNNNNNN }\end{array}$ & $\begin{array}{l}225-9 \\
=216 \\
96 \%\end{array}$ & $\begin{array}{l}29828 / 29846 \\
=18 \\
99.939690 \%\end{array}$ & $\begin{array}{l}\text { HIV2 } \\
\text { cote } \\
\text { d'ivoir } \\
\text { e }\end{array}$ & $\begin{array}{l}24 \text { mar } \\
2020 \\
06 \text { apr } \\
2020\end{array}$ \\
\hline
\end{tabular}




\begin{tabular}{|c|c|c|c|c|c|c|}
\hline & ID: MT263436.1 & NN & $4.000000 \%$ & $0.060309 \%$ & 2014 & \\
\hline 14 USA & $\begin{array}{l}\text { SARS-CoV-2/WA- } \\
\text { UW351/human/2020/USA, } \\
\text { complete genome Sequence } \\
\text { ID: MT263431.1 }\end{array}$ & $\begin{array}{l}189-197 \\
\text { TTCCATGC } \\
\text { TA/NNNNN } \\
\text { NNNN }\end{array}$ & $\begin{array}{l}225-9 \\
=216 \\
\mathbf{9 6 \%} \\
\mathbf{4 . 0 0 0 0 0 0 \%}\end{array}$ & $\begin{array}{l}29834 / 29852 \\
=18 \\
99.939702 \% \\
0.060297 \%\end{array}$ & $\begin{array}{l}\text { HIV2 } \\
\text { cote } \\
\text { d'ivoir } \\
\text { e } \\
2014\end{array}$ & $\begin{array}{l}24 \text { mar } \\
2020 \\
06 \text { apr } \\
2020\end{array}$ \\
\hline 15 USA & $\begin{array}{l}\text { SARS-CoV-2/WA- } \\
\text { UW287/human/2020/USA, } \\
\text { complete genome Sequence } \\
\text { ID: MT259277.1 }\end{array}$ & $\begin{array}{l}\text { 189-197 } \\
\text { TCCATGCT } \\
\text { A/NNNNNN } \\
\text { NNN }\end{array}$ & $\begin{array}{l}225-9 \\
=216 \\
\mathbf{9 6 \%} \\
\mathbf{4 . 0 0 0 0 0 0 \%}\end{array}$ & $\begin{array}{l}29843 / 29866 \\
=23 \\
99.922989 \% \\
0.077011 \%\end{array}$ & $\begin{array}{l}\text { HIV2 } \\
\text { cote } \\
\text { d'ivoir } \\
\text { e } \\
2014\end{array}$ & $\begin{array}{l}15 \text { mar } \\
2020 \\
06 \mathrm{apr} \\
2020\end{array}$ \\
\hline 16 USA & $\begin{array}{l}\text { SARS-CoV-2/WA- } \\
\text { UW306/human/2020/USA, } \\
\text { partial genome Sequence } \\
\text { ID: MT263389.1 }\end{array}$ & $\begin{array}{l}145-191 \\
46 \text { del }\end{array}$ & $\begin{array}{l}225-179 \\
=46 \\
\mathbf{7 9 . 5 5 5 5} \% \\
\mathbf{2 0 . 4 4 4 4 4 \%}\end{array}$ & $\begin{array}{l}29517 / 29598 \\
=81 \\
\mathbf{9 9 . 7 2 6 3 3 2} \% \\
\mathbf{0 . 2 7 3 6 6 7 \%}\end{array}$ & & $\begin{array}{l}23 \text { mar } \\
2020 \\
06 \text { apr } \\
2020\end{array}$ \\
\hline 17 China & $\begin{array}{l}\text { Wuhan seafood market } \\
\text { pneumonia virus genome } \\
\text { assembly, chromosome: } \\
\text { whole_genome } \\
\text { Sequence ID: LR757997.1 }\end{array}$ & $\begin{array}{l}106-225 \\
120 \text { del }\end{array}$ & $\begin{array}{l}225-105 \\
=120 \\
\mathbf{4 6 . 6 6 6 6 \%} \\
\mathbf{5 3 . 3 3 3 3 3 3 \%}\end{array}$ & $\begin{array}{l}19263 / 29388 \\
=10125 \\
\mathbf{6 5 . 5 4 7 1 6 2} \% \\
\mathbf{3 4 . 4 5 2 8 3 8 \%}\end{array}$ & $\begin{array}{l}\text { HIV2 } \\
\text { cote } \\
\text { d'ivoir } \\
\text { e } \\
2014 \\
\text { and } \\
\text { SIV } \\
\text { Africa } \\
2016\end{array}$ & $\begin{array}{l}31 \mathrm{dec} \\
2019 \\
06 \text { mar } \\
20209\end{array}$ \\
\hline
\end{tabular}

In Table 9, results involving 6 significant genomes show a great average mutations level in each 225bases regions ( $\mathbf{1 3 . 5 6 8 7 \%}$ ) than in their relating whole genomes $(\mathbf{0 . 3 4 9 6 \%})$. Then a ratio between average rate mutations region 225 bases and average rate mutations whole genome $=\mathbf{3 8 . 8 1 3}$, due principally to the wuhan market hyper deleted genome LR757997.1

Note : last line ref17 China has a lot of deleted or « N » regions : 19263 TCAG nucleotides on 29470 length, then 10207 nucleotides deletions or undetermined nucleotides regions.

The following Figure6 illustrates these strong results.

Time Evolution for USA COVID_19 225b and whole genome mutations rate \% we considere only significant mutations and deletions (values are $\times 100$ )

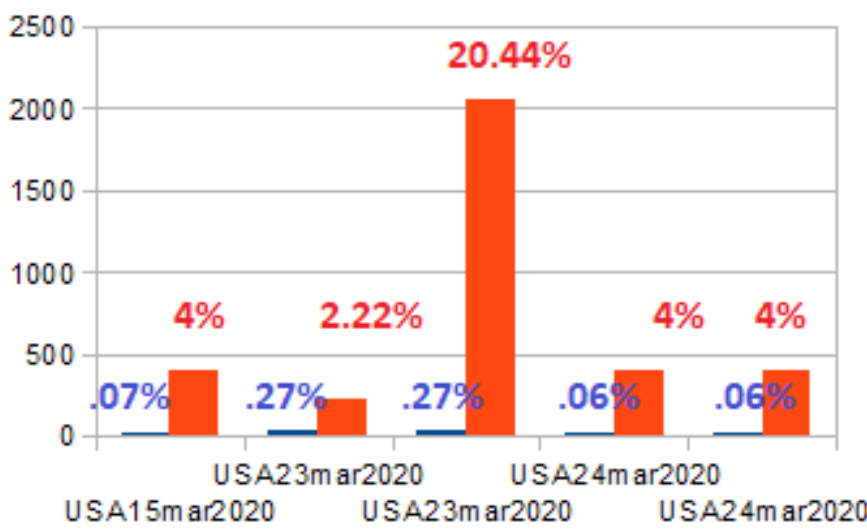

whole genome mut. Rate

225 b mut. Rate

Figure 6 - From Table 9, this chart show comparative time evolution between Seattle (WA) first mutations/deletions rates $\%$ at whole genome and $225 \mathrm{~b}$ levels. 
Figure 6 illustrates for 5 COVID_19 USA strains collected from NCBI data banks in April 2020, the mutation rate from 225 bases regions and whole genomes. In all cases, the mutation rate is greather at 225 bases region that at whole genome scale.

Now, we run same research for high density EIE regions « $A$ » and « $B$ » :

==> ==> The 2 Tables (Table Ref 6.1 and Table Ref 6.2) are available in Supplementary Materials Ref 6:

InTableRef 6.1 - Region « A » interesting mutations, and in Table Ref 6.2 - Region « B » interesting mutations. We demonstrates then reinforces the same kind of results :

For region « $A$ » analysis (Table Ref 6.1), we note that 5 different HIV/SIV EIE and 5 mutations regions are matching within the 8 different COVID_19 strains.

Supplementary Materials

For region « $B$ » analysis (Table Ref 6.2), we note that 20 different HIV/SIV EIE and 13 mutations regions are matching within the 13 different COVID_19 strains.

Supplementary Materials

The following Figure7 illustrates these strong results.

Figure 7 illustrates for 5 COVID_19 USA strains collected from NCBI data banks in April 2020, the mutation rate from regions « $A$ ॥ « $B$ » (then 600+330bases) regions and whole genomes. In all cases, the mutation rate is greather at regions $« A »+\ll B »$ region that at whole genome scale.

\section{Firsts COVID_19 mutations in USA particularly WA and firstMN cases}

Regions $\mathrm{A}+\mathrm{B}$ mutation rate > whole geno me mutation rate

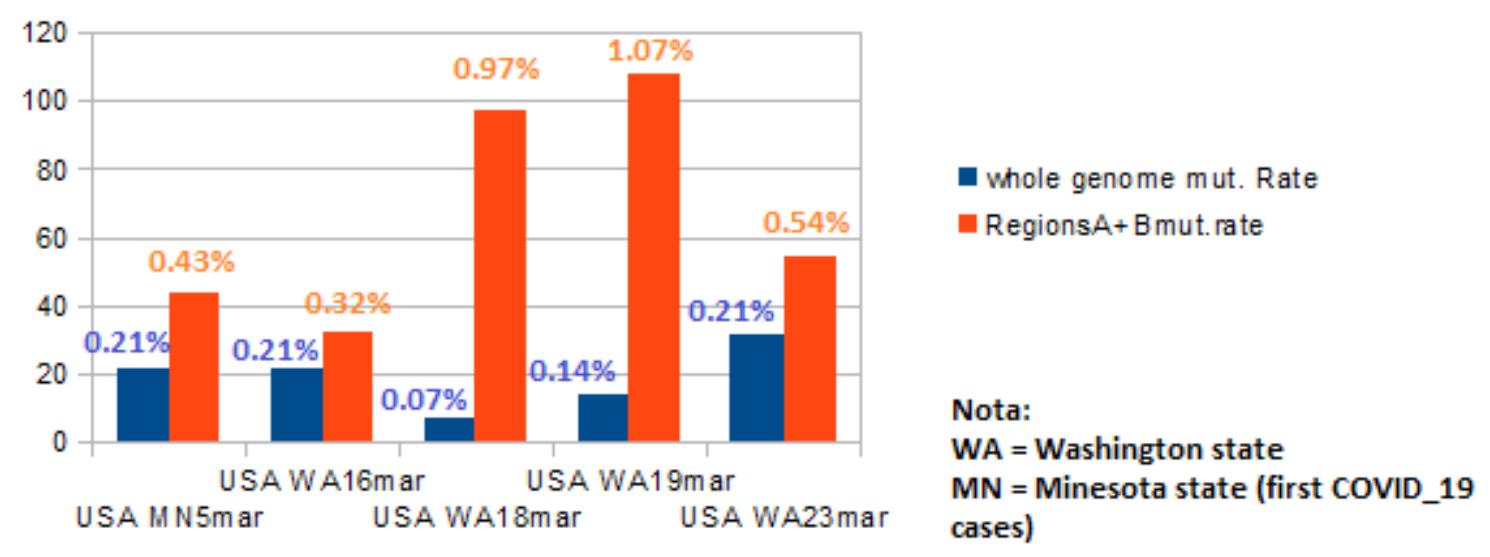

Figure 7 - This other chart show comparative time evolution between (WA and Minesota strains first mutations) and mutations/deletions rates $\%$ at whole genome and in the case of region 930 bases = region « $A$ » (600bases) + region « $B$ » (330 bases).

Some conclusions on the geographical evolution of the genome:

In China, the strains seem to have changed very little in mutations (with the exception of Wuhan seafood market pneumonia virus genome assembly, chromosome: whole_genome Sequence ID: LR757997.1). In Italy and in France, we find no remarkable mutation vis-à-vis the Chinese reference genome.

It is in Spain and the USA that we detect the most blatant traces of a notorious evolution of the genome:

In Spain, recent sequences (March 2020) demonstrate significant deletions and mutations in regions containing EIE. According to the first results of analyzes [13], this genome would not have increased its pathogenicity and would seem to use new modes of transmission. 
In the USA, the analysis of multiple sequences from the Seatle region (WA) and Minnesota shows a clear growing trees progressiveness in the mutations then successive deletions of the regions "A", "B" and 225 bases, thus:

Table8 (ref 1 to 7 , then 11 to 13), we progress from simple mutations to longer mutations on 3 codons, they affect HIV / SIV EIE.

Table Ref 6.1 (from Sup. Materials): also, there are grouped mutations (ref 4,5) affecting EIE areas.

Table Ref 6.2 (from Sup. Materials): here we illustrate at best a sort of "shedding" of EIE regions in which these genomes progress: thus, (ref 3567 ), the mutations affect 2 or 3 , then 8 consecutive bases.

Then (9 1011 12), in addition to other new mutations, it is whole pieces, on several tens of bases of the genome which are deleted. The most remarkable point is that in all these cases, it is indeed EIE regions which are targeted.

On the most recent date of April 23, 2020, we can check how other COVID_19 strains from Seatle WA have new deletions located in regions " $\mathrm{A}$ " and "B" of our article. It is deletions that are "shedding" in part of the EIE HIV / SIV located in region "A" and also in region "B", particularly in the "side by side" EIE (see in Table 1: HIV1 Malawi 2013, HIV1 Russia 2010, SIV Cameroon 2015). There is the case particularly for:

Sequence ID: MT188341.1Severe acute respiratory syndrome coronavirus 2 isolate SARS-CoV-

2/human/USA/WA-UW386/2020, partial genome

Length: 29835 collected 5mar2020, sequenced13mar2020,

Sequence ID: MT263466.1 Severe acute respiratory syndrome coronavirus 2 isolate SARS-CoV2/human/USA/WA-UW386/2020, partial genome

Length: 29634 _collected 16mar2020, sequenced 15apr2020

Sequence ID: MT263385.1 Severe acute respiratory syndrome coronavirus 2 isolate SARS-CoV2/human/USA/WA-UW302/2020, partial genome

Length: 29610 collected 23mar2020, sequenced 15apr2020

Sequence ID: MT293224.1 Severe acute respiratory syndrome coronavirus 2 isolate SARS-CoV2/human/USA/WA-UW-1608/2020, complete genome

Length: 29847 collected 18mar2020, sequenced 15apr2020

Sequence ID: MT293213.1 Severe acute respiratory syndrome coronavirus 2 isolate SARS-CoV2/human/USA/WA-UW-1574/2020, complete genome

Length: 29887 collected 19mar2020, sequenced 15apr2020

\section{9 - Systematic generalization of the analysis of 225 bases regions for genomes of recent USA patients who have mutated.}

In order to formally demonstrate the specificity of this region of 225 bases located from base 21542 of 225 bases, we are exploring regions of the same size every 5000 bases throughout the genome of COVID_19. Let be from bases $1542,6542,11542,16542,26542$. We can then deny or affirm the fact that this region of 225 bases that we have highlighted would indeed have a tendency to mutate or even to be partially deleted as this seems to appear for certain WA Seattle strains reported here (Figure 8). Table 10 below shows how the mutation rate of the $225 \mathrm{~b}$ region is always much higher than that of the 5 regions $225 \mathrm{~b}$ explored every 5000 bases (34.82 times).

Table 10 - This Table summarizes remarkable results: they demonstrate the exclusive specificity of the 225bases region which appears here in an obvious way to mutate in priority, probably in order to get rid of the exogenous EIE regions characterizing this region. 


\begin{tabular}{|c|c|c|c|c|c|c|c|c|c|c|}
\hline $\begin{array}{l}\text { Strain } \\
\text { numbe } \\
r\end{array}$ & $\begin{array}{l}\text { Strain } \\
\text { reference }\end{array}$ & $\begin{array}{l}\text { Mutation } \\
\text { S } \\
\text { relatives } \\
\text { adresses } \\
\text { within } \\
225 \\
\text { bases } \\
\text { region }\end{array}$ & \begin{tabular}{|l|} 
Homologie \\
s \\
region \\
225b / \\
same \\
region in \\
reference \\
genome \\
LR757998.1 \\
and \\
mutations \\
rate \%
\end{tabular} & $\begin{array}{l}\text { Homologi } \\
\text { es } \\
\text { whole } \\
\text { genomes } \\
\text { I } \\
\text { whole } \\
\text { reference } \\
\text { genome } \\
\text { LR757998.1 } \\
\text { and } \\
\text { mutations } \\
\text { rate \% }\end{array}$ & $\begin{array}{l}20 \mathrm{~kb} \\
\text { Upstr } \\
\text { eam } \\
\text { area } \\
225 \\
\\
\end{array}$ & $\begin{array}{l}15 \mathrm{~kb} \\
\text { Upstr } \\
\text { eam } \\
\text { area } \\
225\end{array}$ & $\begin{array}{l}10 \mathrm{~kb} \\
\text { Upstr } \\
\text { eam } \\
\text { area } \\
225\end{array}$ & $\begin{array}{l}5 \mathrm{kbUp} \\
\text { strea } \\
\mathrm{m} \\
\text { area } \\
225\end{array}$ & $\begin{array}{l}5 \mathrm{~kb} \\
\text { Down } \\
\text { strea } \\
\mathrm{m} \\
\text { area } \\
225\end{array}$ & \begin{tabular}{|l} 
Ratio \\
area \\
225b / \\
averag \\
e 5 \\
others \\
225b \\
areas
\end{tabular} \\
\hline $\begin{array}{l}12 \text { USA } \\
\text { WA } \\
23 \mathrm{mar} \\
2020\end{array}$ & \begin{tabular}{|l|} 
SARS-CoV- \\
2/WA- \\
UW302/human \\
/2020/USA, \\
partial genome \\
Sequence \\
ID: MT263385.1
\end{tabular} & $\begin{array}{l}175-176 \\
\text { CA/NN } \\
164-166 \\
\text { CCT/NN } \\
N\end{array}$ & $\begin{array}{l}220 / 225 \\
\text { 97.7\% } \\
\mathbf{2 . 2 2 2 2 2 2} \%\end{array}$ & $\begin{array}{l}29517 / \\
29598 \\
=\quad 81 \\
99.72633 \\
3 \% \\
0.273667 \\
\%\end{array}$ & $0,00 \%$ & $0,00 \%$ & $\begin{array}{l}197 \\
\text { A/T } \\
\text { 0.44\% }\end{array}$ & $0,00 \%$ & $\begin{array}{l}183- \\
185 \\
\text { CAC/ } \\
\text { NNN } \\
1.33 \%\end{array}$ & $\begin{array}{l}6.24 \\
\text { Times }\end{array}$ \\
\hline $\begin{array}{l}13 \text { USA } \\
\text { WA } \\
24 \mathrm{mar} \\
2020\end{array}$ & $\begin{array}{r}\text { SARS-CoV- } \\
2 / \text { WA- } \\
\text { UW356/human } \\
\text { /2020/USA, } \\
\text { complete } \\
\text { genome } \\
\text { Sequence } \\
\text { ID: MT263436.1 }\end{array}$ & $\begin{array}{l}\text { 188-196 } \\
\text { TTCCAT } \\
\text { GCT/ } \\
\text { NNNNNN } \\
\text { NNN } \\
\\
\end{array}$ & \begin{tabular}{|l|}
$225-9$ \\
$=216$ \\
$\mathbf{9 6 \%}$ \\
$\mathbf{4 . 0 0 0 0 0 0 \%}$
\end{tabular} & $\begin{array}{l}29828 / \\
29846 \\
=\quad 18 \\
99.93969 \\
0 \% \\
0.060309 \\
\%\end{array}$ & $0,00 \%$ & $0,00 \%$ & $\begin{array}{l}197 \\
\text { A/T } \\
0.44 \%\end{array}$ & $0,00 \%$ & $0,00 \%$ & \begin{tabular}{|l}
45 \\
Times
\end{tabular} \\
\hline $\begin{array}{l}14 \text { USA } \\
\text { WA } \\
24 \mathrm{mar} \\
2020\end{array}$ & $\begin{array}{l}\text { SARS-CoV- } \\
\text { 2/WA- } \\
\text { UW351/human/ } \\
\text { 2020/USA, } \\
\text { complete } \\
\text { genome } \\
\text { Sequence } \\
\text { ID: MT263431.1 }\end{array}$ & $\begin{array}{l}\text { 189-197 } \\
\text { TTCCAT } \\
\text { GCTA/N } \\
\text { NNNNNN } \\
\text { NN }\end{array}$ & \begin{tabular}{|l|}
$225-9$ \\
$=216$ \\
$\mathbf{9 6 \%}$ \\
$\mathbf{4 . 0 0 0 0 0 0 \%}$
\end{tabular} & $\begin{array}{l}29834 / \\
29852 \\
=\quad 18 \\
99.93970 \\
2 \% \\
0.060297 \\
\%\end{array}$ & $0,00 \%$ & $0,00 \%$ & $\begin{array}{l}197 \\
\text { A/T } \\
0.44 \%\end{array}$ & $0,00 \%$ & $0 \%$ & $\begin{array}{l}45 \\
\text { Times }\end{array}$ \\
\hline $\begin{array}{l}15 \text { USA } \\
\text { WA } \\
15 \mathrm{mar} \\
2020\end{array}$ & \begin{tabular}{|l|} 
SARS-CoV- \\
2/WA- \\
UW287/human \\
/2020/USA, \\
complete \\
genome \\
Sequence \\
ID: MT259277.1 \\
\end{tabular} & $\begin{array}{l}189-197 \\
\text { TCCATG } \\
\text { CTA/NNN } \\
\text { NNNNNN }\end{array}$ & \begin{tabular}{|l|}
$225-9$ \\
$=216$ \\
$96 \%$ \\
$4.000000 \%$
\end{tabular} & \begin{tabular}{|l}
$29843 /$ \\
29866 \\
$=23$ \\
99.92298 \\
$9 \%$ \\
0.077011 \\
$\%$
\end{tabular} & $0,00 \%$ & $0,00 \%$ & $\begin{array}{l}197 \\
\text { A/T } \\
0.44 \%\end{array}$ & $0,00 \%$ & $0,00 \%$ & $\begin{array}{l}45 \\
\text { Times }\end{array}$ \\
\hline $\begin{array}{l}16 \text { USA } \\
\text { WA } \\
23 \mathrm{mar} \\
2020\end{array}$ & $\begin{array}{l}\text { SARS-CoV- } \\
\text { 2/WA- } \\
\text { UW306/human } \\
\text { /2020/USA, } \\
\text { partial genome } \\
\text { Sequence } \\
\text { ID: } \text { MT263389.1 }\end{array}$ & $\begin{array}{l}145-191 \\
46 \text { del }\end{array}$ & \begin{tabular}{|l|}
$225-179$ \\
$=46$ \\
$\mathbf{7 9 . 5 5 5 5 \%}$ \\
$\mathbf{2 0 . 4 4 4 4 4 \%}$
\end{tabular} & $\begin{array}{l}29517 / \\
29598 \\
=\quad 81 \\
99.72633 \\
2 \% \\
0.273667 \\
\%\end{array}$ & \begin{tabular}{|l|}
129 \\
G/A \\
$0.44 \%$
\end{tabular} & $0,00 \%$ & $\begin{array}{l}197 \\
\text { A/T } \\
0.44 \%\end{array}$ & $0,00 \%$ & $\begin{array}{l}131- \\
135 \\
\text { CAGT } \\
\text { A/NN } \\
\text { NNN } \\
2.222 \\
2 \%\end{array}$ & $\begin{array}{l}32.86 \\
\text { Times }\end{array}$ \\
\hline
\end{tabular}

The following Figure 8 illustrates these strong results. 
Systematic 225b area scanning for recent USA WA patients who have mutated

ALL 225b cases analyzed have LOWER mutation-rate than that of the $225 \mathrm{~b}$ area

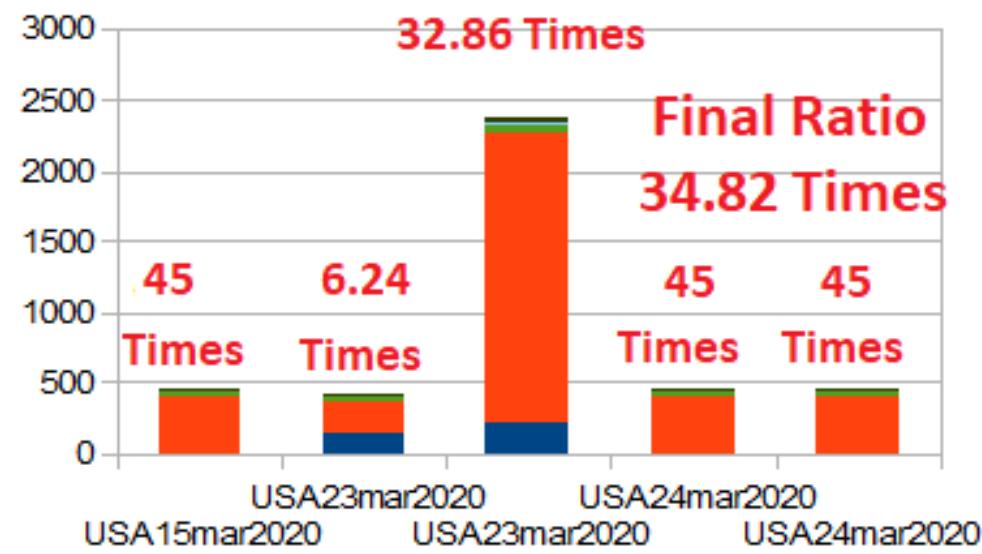

whole genome mut. Rate

$20 \mathrm{~kb}$ upstream

- $15 \mathrm{~kb}$ upstream

- $10 \mathrm{~kb}$ upstream

- $5 \mathrm{~kb}$ upstream

- 225b mut. Rate

- $5 \mathrm{~kb}$ downstream

Ratios between the

main 225b area (RED) / average of the 5 others $225 b$ areas

Figure 8 - This Figure summarizes these remarkable results: they demonstrate (RED areas) the exclusive specificity of the 225 bases region which appears here in an obvious way to mutate in priority, probably in order to get rid of the exogenous EIE regions characterizing this region.

\section{0- New evidence of increased deletions from region 225b in WA State in the USA.}

As of May 2, 2020, we wanted to assess whether the 225b region of the COVID-19 strains continued to mutate in the WA state region in particular. Out of 1578 COVID_19 strains accessible to date, 32 presented significant mutations (more than 2 bases out of 225). Among them, 30 came from the USA (see table 12 below and Figure 9), the last 2 from Wuhan and the Czech Republic are not considered here. Among these 30 USA strains, 22 came from the state of WA, 5 from CA, 2 from Utah, and 1 from the state of New York.

The 3 most remarkable facts are:

On the one hand, a great diversity of places and types of mutations and deletions in the region of 225 bases. It will be interesting to locate these mutations vis-à-vis the positions of the 4 EIEs in this region.

On the other hand, new types of mutations are also appearing in states other than WA, in California in particular. We can conclude from this that this key region of 225 bases continues to be shed from its genome by the virus COVID_19.

Thirtly, there is a high variety and diversity of mutations and deletes: On these 30 USA cases, 20 cases are totally different mutation/deletions configurations.

Table 11 - This Table demontrates expansion and diversity of 225b region on 2 May 2020, particularly in WA Seattle USA state.

\begin{tabular}{|l|l|l|l|}
\hline Reference & Strain description & $\begin{array}{l}\text { Mutations/del } \\
\text { etions }\end{array}$ & $\begin{array}{l}\text { Mutat } \\
\text { ions } \\
\text { rate }\end{array}$ \\
\hline $\begin{array}{l}\text { USA CA } \\
\text { 28mar2020 }\end{array}$ & $\begin{array}{l}\text { Severe acute respiratory syndrome coronavirus 2 isolate SARS-CoV- } \\
\text { 2/human/USA/CA-CZB-IX00112/2020, complete genome Sequence } \\
\text { ID: MT385489.1 }\end{array}$ & 121 CAGAT/5N & $2.22 \%$ \\
\hline
\end{tabular}




\begin{tabular}{|c|c|c|c|}
\hline $\begin{array}{l}\text { USA CA } \\
28 \text { mar2020 }\end{array}$ & $\begin{array}{l}\text { Severe acute respiratory syndrome coronavirus } 2 \text { isolate SARS-CoV- } \\
\text { 2/human/USA/WA-UW302/2020, partial genome } \\
\text { Sequence ID: MT263385.1 }\end{array}$ & $\begin{array}{l}164-166 \\
\mathrm{CCT} / \mathrm{NNN} \\
175-176 \mathrm{CA} / \mathrm{NN}\end{array}$ & $\begin{array}{l}2.22 \% \\
(1 / 5)\end{array}$ \\
\hline $\begin{array}{l}\text { USA WA } \\
23 \text { mar2020 }\end{array}$ & $\begin{array}{l}\text { Severe acute respiratory syndrome coronavirus } 2 \text { isolate SARS-CoV- } \\
\text { 2/human/USA/WA-UW-2225/2020 ORF1ab polyprotein (ORF1ab) and ORF1a } \\
\text { polyprotein (ORF1ab) genes, partial cds; and surface glycoprotein (S), ORF3a } \\
\text { protein (ORF3a), envelope protein (E), membrane glycoprotein (M), ORF6 } \\
\text { protein (ORF6), ORF7a protein (ORF7a), ORF7b (ORF7b), ORF8 protein } \\
\text { (ORF8), nucleocapsid phosphoprotein (N), and ORF10 protein (ORF10) genes, } \\
\text { complete cds Sequence ID: MT345837.1 }\end{array}$ & 177 ATGTTA/6N & $2.66 \%$ \\
\hline $\begin{array}{l}\text { USA CA } \\
23 \operatorname{mar} 2020\end{array}$ & $\begin{array}{l}\text { Severe acute respiratory syndrome coronavirus } 2 \text { isolate SARS-CoV- } \\
\text { 2/human/USA/CA-CZB-EX00700/2020, complete genome Sequence } \\
\text { ID: MT385494.1 }\end{array}$ & $\begin{array}{l}137 \\
\text { TTACATTC/8N }\end{array}$ & $3.55 \%$ \\
\hline $\begin{array}{l}\text { USA WA } \\
20 \text { mar2020 }\end{array}$ & $\begin{array}{l}\text { Severe acute respiratory syndrome coronavirus } 2 \text { isolate SARS-CoV- } \\
\text { 2/human/USA/WA-UW-1765/2020, complete genome Sequence } \\
\text { ID: MT326134.1 }\end{array}$ & $\begin{array}{l}189 \\
\text { TCCATGCTA/9N }\end{array}$ & $4,00 \%$ \\
\hline $\begin{array}{l}\text { USA WA } \\
20 \text { mar2020 }\end{array}$ & $\begin{array}{l}\text { Severe acute respiratory syndrome coronavirus } 2 \text { isolate SARS-CoV- } \\
\text { 2/human/USA/WA-UW-1698/2020, complete genome Sequence } \\
\text { ID: MT326129.1 }\end{array}$ & $\begin{array}{l}189 \\
\text { TCCATGCTA/9N }\end{array}$ & $4,00 \%$ \\
\hline $\begin{array}{l}\text { USA WA } \\
18 \text { mar2020 }\end{array}$ & $\begin{array}{l}\text { Severe acute respiratory syndrome coronavirus } 2 \text { isolate SARS-CoV- } \\
\text { 2/human/USA/WA-UW-1608/2020, complete genome Sequence } \\
\text { ID: MT293224.1 }\end{array}$ & $\begin{array}{l}188 \\
\text { TTCCATGCT/9N }\end{array}$ & $4,00 \%$ \\
\hline $\begin{array}{l}\text { USA WA } \\
19 \text { mar2020 }\end{array}$ & $\begin{array}{l}\text { Severe acute respiratory syndrome coronavirus } 2 \text { isolate SARS-CoV- } \\
\text { 2/human/USA/WA-UW-1574/2020, complete genome Sequence } \\
\text { ID: MT293213.1 }\end{array}$ & $\begin{array}{l}189 \\
\text { TCCATGCTA/9N }\end{array}$ & $4,00 \%$ \\
\hline $\begin{array}{l}\text { USA WA } \\
19 \text { mar2020 }\end{array}$ & $\begin{array}{l}\text { Severe acute respiratory syndrome coronavirus } 2 \text { isolate SARS-CoV- } \\
\text { 2/human/USA/WA-UW-1603/2020, complete genome Sequence } \\
\text { ID: MT293200.1 }\end{array}$ & $\begin{array}{l}189 \\
\text { TCCATGCTA/9N }\end{array}$ & $4,00 \%$ \\
\hline $\begin{array}{l}\text { USA WA } \\
19 \text { mar2020 }\end{array}$ & $\begin{array}{l}\text { Severe acute respiratory syndrome coronavirus } 2 \text { isolate SARS-CoV- } \\
\text { 2/human/USA/WA-UW-1583/2020, complete genome Sequence } \\
\text { ID: MT293198.1 }\end{array}$ & $\begin{array}{l}189 \\
\text { TCCATGCTA/9N }\end{array}$ & $4,00 \%$ \\
\hline $\begin{array}{l}\text { USA WA } \\
19 \text { mar2020 }\end{array}$ & $\begin{array}{l}\text { Severe acute respiratory syndrome coronavirus } 2 \text { isolate SARS-CoV- } \\
\text { 2/human/USA/WA-UW-1567/2020, complete genome Sequence } \\
\text { ID: MT293196.1 }\end{array}$ & $\begin{array}{l}189 \\
\text { TCCATGCTA/9N }\end{array}$ & $4,00 \%$ \\
\hline $\begin{array}{l}\text { USA WA } \\
24 \text { mar2020 }\end{array}$ & $\begin{array}{l}\text { Severe acute respiratory syndrome coronavirus } 2 \text { isolate SARS-CoV- } \\
\text { 2/human/USA/WA-UW356/2020, complete genome Sequence } \\
\text { ID: MT263436.1 }\end{array}$ & $\begin{array}{l}188 \\
\text { TTCCATGCT/9N }\end{array}$ & $\begin{array}{l}4,00 \% \\
(2 / 5)\end{array}$ \\
\hline $\begin{array}{l}\text { USA WA } \\
24 \text { mar2020 }\end{array}$ & $\begin{array}{l}\text { Severe acute respiratory syndrome coronavirus } 2 \text { isolate SARS-CoV- } \\
\text { 2/human/USA/WA-UW351/2020, complete genome Sequence } \\
\text { ID: MT263431.1 }\end{array}$ & $\begin{array}{l}189 \\
\text { TCCATGCTA/9N }\end{array}$ & $\begin{array}{l}4,00 \% \\
(3 / 5)\end{array}$ \\
\hline $\begin{array}{l}\text { USA WA } \\
15 \text { mar2020 }\end{array}$ & $\begin{array}{l}\text { Severe acute respiratory syndrome coronavirus } 2 \text { isolate SARS-CoV- } \\
\text { 2/human/USA/WA-UW287/2020, complete genome Sequence } \\
\text { ID: MT259277.1 }\end{array}$ & $\begin{array}{l}189 \\
\text { TCCATGCTA/9N }\end{array}$ & $\begin{array}{l}4,00 \% \\
(4 / 5)\end{array}$ \\
\hline $\begin{array}{l}\text { USA WA } \\
21 \text { mar2020 }\end{array}$ & $\begin{array}{l}\text { Severe acute respiratory syndrome coronavirus } 2 \text { isolate SARS-CoV- } \\
\text { 2/human/USA/WA-UW-1758/2020 ORF1ab polyprotein (ORF1ab), ORF1a } \\
\text { polyprotein (ORF1ab), surface glycoprotein (S), ORF3a protein (ORF3a), } \\
\text { envelope protein (E), membrane glycoprotein (M), ORF6 protein (ORF6), } \\
\text { ORF7a protein (ORF7a), ORF7b (ORF7b), ORF8 protein (ORF8), nucleocapsid } \\
\text { phosphoprotein (N), and ORF10 protein (ORF10) genes, complete cds } \\
\text { Sequence ID: MT326171.1 }\end{array}$ & $\begin{array}{l}188 \\
\text { TTCCATGCT/9N }\end{array}$ & $4,00 \%$ \\
\hline $\begin{array}{l}\text { USA WA } \\
24 \operatorname{mar} 2020\end{array}$ & $\begin{array}{l}\text { Severe acute respiratory syndrome coronavirus } 2 \text { isolate SARS-CoV- } \\
\text { 2/human/USA/WA-UW-1963/2020 ORF1ab polyprotein (ORF1ab) and ORF1a } \\
\text { polyprotein (ORF1ab) genes, partial cds; surface glycoprotein (S), ORF3a } \\
\text { protein (ORF3a), and envelope protein (E) genes, complete cds; M gene, partial } \\
\text { sequence; ORF6 gene, complete sequence; and ORF7a protein (ORF7a), ORF7b } \\
\text { (ORF7b), ORF8 protein (ORF8), nucleocapsid phosphoprotein (N), and ORF10 } \\
\text { protein (ORF10) genes, complete cds }\end{array}$ & $\begin{array}{l}106-118 \\
\text { TTACCCTGACA } \\
\text { AA/13N }\end{array}$ & $5.77 \%$ \\
\hline
\end{tabular}




\begin{tabular}{|c|c|c|c|}
\hline & Sequence ID: MT326080.1 & & \\
\hline $\begin{array}{l}\text { USA WA } \\
28 \text { mar2020 }\end{array}$ & $\begin{array}{l}\text { Severe acute respiratory syndrome coronavirus } 2 \text { isolate SARS-CoV- } \\
\text { 2/human/USA/WA-UW-4749/2020, complete genome Sequence } \\
\text { ID: MT375449.1 }\end{array}$ & $\begin{array}{l}143-152 \\
\text { TCAACTCAGG/1 } \\
0 \mathrm{~N} \\
156 \mathrm{~T} / \mathrm{G} \\
158 \mathrm{~T} / \mathrm{A} \\
162 \mathrm{~T} / \mathrm{D} \\
165 \mathrm{C} / \mathrm{T}\end{array}$ & $6.22 \%$ \\
\hline $\begin{array}{l}\text { USA CA } \\
8 \text { avr2020 }\end{array}$ & $\begin{array}{l}\text { Severe acute respiratory syndrome coronavirus } 2 \text { isolate SARS-CoV- } \\
\text { 2/human/USA/CA-CZB-IX00141/2020, complete genome Sequence } \\
\text { ID: MT385478.1 }\end{array}$ & $\begin{array}{l}\text { Del } 32 \text { bases } 194- \\
225\end{array}$ & $14.22 \%$ \\
\hline $\begin{array}{l}\text { USA NY } \\
22 \text { mar2020 }\end{array}$ & $\begin{array}{l}\text { Severe acute respiratory syndrome coronavirus } 2 \text { isolate SARS-CoV- } \\
\text { 2/human/USA/NY-PV09161/2020 ORF1ab polyprotein (ORF1ab) gene, partial } \\
\text { cds; ORF1a polyprotein (ORF1ab) gene, complete cds; surface glycoprotein (S) } \\
\text { gene, partial cds; and ORF3a protein (ORF3a), envelope protein (E), membrane } \\
\text { glycoprotein (M), ORF6 protein (ORF6), ORF7a protein (ORF7a), ORF7b } \\
\text { (ORF7b), ORF8 protein (ORF8), nucleocapsid phosphoprotein (N), and ORF10 } \\
\text { protein (ORF10) genes, complete cds } \\
\text { Sequence ID: MT371011.1 }\end{array}$ & Del 32 bases $1-32$ & $14.22 \%$ \\
\hline $\begin{array}{l}\text { USA WA } \\
27 \text { mar2020 }\end{array}$ & $\begin{array}{l}\text { Severe acute respiratory syndrome coronavirus } 2 \text { isolate SARS-CoV- } \\
\text { 2/human/USA/WA-UW-4744/2020, complete genome Sequence } \\
\text { ID: MT375448.1 }\end{array}$ & $\begin{array}{l}166-178 \\
\text { TTTCTTTTCCAA } \\
\text { T/13N } \\
\text { Del } 12214-225\end{array}$ & $11.11 \%$ \\
\hline $\begin{array}{l}\text { USA CA } \\
25 \text { mar2020 }\end{array}$ & $\begin{array}{l}\text { Severe acute respiratory syndrome coronavirus } 2 \text { isolate SARS-CoV- } \\
\text { 2/human/USA/CA-CZB-IX00017/2020, complete genome } \\
\text { Sequence ID: MT385497.1 }\end{array}$ & $\begin{array}{l}125-144 \\
\text { AGATCCTCAGT } \\
\text { TTTACATTC/20N }\end{array}$ & $8.88 \%$ \\
\hline $\begin{array}{l}\text { USA WA } \\
\text { 9mar2020 }\end{array}$ & $\begin{array}{l}\text { Severe acute respiratory syndrome coronavirus } 2 \text { isolate SARS-CoV- } \\
\text { 2/human/USA/WA-UW71/2020, complete genome Sequence ID: } \text { MT252799.1 }\end{array}$ & $\begin{array}{l}\text { Del } 42 \text { bases } 184- \\
225\end{array}$ & $18.66 \%$ \\
\hline $\begin{array}{l}\text { USA WA } \\
\text { 6avr2020 }\end{array}$ & $\begin{array}{l}\text { Severe acute respiratory syndrome coronavirus } 2 \text { isolate SARS-CoV- } \\
\text { 2/human/USA/WA-UW-4707/2020, complete genome Sequence } \\
\text { ID: MT375462.1 }\end{array}$ & $\begin{array}{l}107-128 \\
\text { TACCCTGACAA } \\
\text { AGTTTTCAGAT/ } \\
22 \mathrm{~N}\end{array}$ & $9.77 \%$ \\
\hline $\begin{array}{l}\text { USA WA } \\
16 \text { mar2020 }\end{array}$ & $\begin{array}{l}\text { Severe acute respiratory syndrome coronavirus } 2 \text { isolate SARS-CoV- } \\
\text { 2/human/USA/WA-UW306/2020, partial genome Sequence ID: MT263389.1 }\end{array}$ & $\begin{array}{l}\text { Del } 47 \text { bases } 145- \\
191\end{array}$ & $\begin{array}{l}20.88 \% \\
(5 / 5)\end{array}$ \\
\hline $\begin{array}{l}\text { USA WA } \\
\text { 20mar2020 }\end{array}$ & $\begin{array}{l}\text { Severe acute respiratory syndrome coronavirus } 2 \text { isolate SARS-CoV- } \\
\text { 2/human/USA/WA-UW-1673/2020 ORF1ab polyprotein (ORF1ab) and ORF1a } \\
\text { polyprotein (ORF1ab) genes, partial cds; and surface glycoprotein (S), ORF3a } \\
\text { protein (ORF3a), envelope protein (E), membrane glycoprotein (M), ORF6 } \\
\text { protein (ORF6), ORF7a protein (ORF7a), ORF7b (ORF7b), ORF8 protein } \\
\text { (ORF8), nucleocapsid phosphoprotein (N), and ORF10 protein (ORF10) genes, } \\
\text { complete cds Sequence ID: MT326131.1 }\end{array}$ & $\begin{array}{l}\text { Del } 60 \text { bases } 132- \\
191 \\
220 \mathrm{~A} / \mathrm{N}\end{array}$ & $27.11 \%$ \\
\hline $\begin{array}{l}\text { USA WA } \\
23 \text { mar2020 }\end{array}$ & $\begin{array}{l}\text { Severe acute respiratory syndrome coronavirus } 2 \text { isolate SARS-CoV- } \\
\text { 2/human/USA/WA-UW-2220/2020 ORF1ab polyprotein (ORF1ab) and ORF1a } \\
\text { polyprotein (ORF1ab) genes, partial cds; surface glycoprotein (S) and ORF3a } \\
\text { protein (ORF3a) genes, complete cds; envelope protein (E) and membrane } \\
\text { glycoprotein (M) genes, partial cds; and ORF6 protein (ORF6), ORF7a protein } \\
\text { (ORF7a), ORF7b (ORF7b), ORF8 protein (ORF8), nucleocapsid } \\
\text { phosphoprotein (N), and ORF10 protein (ORF10) genes, complete cds } \\
\text { Sequence ID: MT345839.1 }\end{array}$ & $\begin{array}{l}\text { Del 53bases 129- } \\
181\end{array}$ & $23.55 \%$ \\
\hline $\begin{array}{l}\text { USA UT } \\
25 \text { mar2020 }\end{array}$ & $\begin{array}{l}\text { Severe acute respiratory syndrome coronavirus } 2 \text { isolate SARS-CoV- } \\
\text { 2/human/USA/UT-00302/2020 ORF1ab polyprotein (ORF1ab) gene, partial cds; } \\
\text { ORF1a polyprotein (ORF1ab) gene, complete cds; surface glycoprotein (S) gene, } \\
\text { partial cds; ORF3a protein (ORF3a) gene, complete cds; envelope protein (E) } \\
\text { and membrane glycoprotein (M) genes, partial cds; ORF6 protein (ORF6) gene, } \\
\text { complete cds; ORF7a protein (ORF7a) and ORF7b (ORF7b) genes, partial cds; } \\
\text { ORF8 protein (ORF8) gene, complete cds; nucleocapsid phosphoprotein (N) } \\
\text { gene, partial cds; and ORF10 gene, complete sequence } \\
\text { Sequence ID: MT334562.1 }\end{array}$ & Del 99 bases 1-99 & $44,00 \%$ \\
\hline $\begin{array}{l}\text { USA CA } \\
31 \mathrm{mar} 2020\end{array}$ & $\begin{array}{l}\text { Severe acute respiratory syndrome coronavirus } 2 \text { isolate SARS-CoV- } \\
\text { 2/human/USA/CA-CZB-EX00719/2020, complete genome Sequence } \\
\text { ID: MT385496.1 }\end{array}$ & $\begin{array}{l}\text { Del } 102 \text { bases } \\
124-225\end{array}$ & $45.33 \%$ \\
\hline
\end{tabular}




\begin{tabular}{|l|l|l|l|}
\hline USA UT & $\begin{array}{l}\text { Severe acute respiratory syndrome coronavirus 2 isolate SARS-CoV- } \\
\text { 2/human/USA/UT-00087/2020 ORF1ab polyprotein (ORF1ab), ORF1a } \\
\text { polyprotein (ORF1ab), surface glycoprotein (S), ORF3a protein (ORF3a), } \\
\text { envelope protein (E), and membrane glycoprotein (M) genes, partial cds; ORF6 } \\
\text { protein (ORF6) gene, complete cds; ORF7a protein (ORF7a) gene, partial cds; } \\
\text { ORF7b gene, complete sequence; ORF8 protein (ORF8) gene, partial cds; and } \\
\text { nucleocapsid phosphoprotein (N) and ORF10 protein (ORF10) genes, complete } \\
\text { cds Sequence ID: MT334549.1 }\end{array}$ & $\begin{array}{l}\text { Del } 103 \text { bases } \\
103\end{array}$ & $45.77 \%$ \\
\hline $\begin{array}{l}\text { China Wuhan } \\
\text { 31dec2019 }\end{array}$ & $\begin{array}{l}\text { Wuhan seafood market pneumonia virus genome assembly, chromosome: } \\
\text { whole_genome Sequence ID: LR757997.1 }\end{array}$ & $\begin{array}{l}\text { Del } 120 \text { bases } \\
106-225\end{array}$ & $\begin{array}{l}53.33 \% \\
(5)\end{array}$ \\
\hline $\begin{array}{l}\text { USA WA } \\
\text { 31mar2020 }\end{array}$ & $\begin{array}{l}\text { Severe acute respiratory syndrome coronavirus } 2 \text { isolate SARS-CoV- } \\
\text { 2/human/USA/WA-UW-4582/2020, complete genome Sequence } \\
\text { ID: MT375436.1 }\end{array}$ & $\begin{array}{l}\text { Del } 190 \text { bases } 36- \\
225\end{array}$ & $84.44 \%$ \\
\hline
\end{tabular}

Note1 to Note5 : these COVID_19 USA strains selected on our BLASTn April scanning (Table 9 and Figure 6 ) will be re-used, here, in Table 11 and Figure 9. Then, we could compare 225bases genome evolution and increasing mutations rate between April and May BLASTn scanning analyses, particularly in the cases of USA WA state COVID_19 strains.

This Table demontrates expansion and diversity of 225b region on 2 May 2020, particularly in WA Seattle USA state.

Figure 9 - Analysing mutations/deletions within 32 COVID_19 225bases region on 2 may 2020.

\section{5 bases region Mutations rate diversity and Evolution 11Apr to 2May 2020}

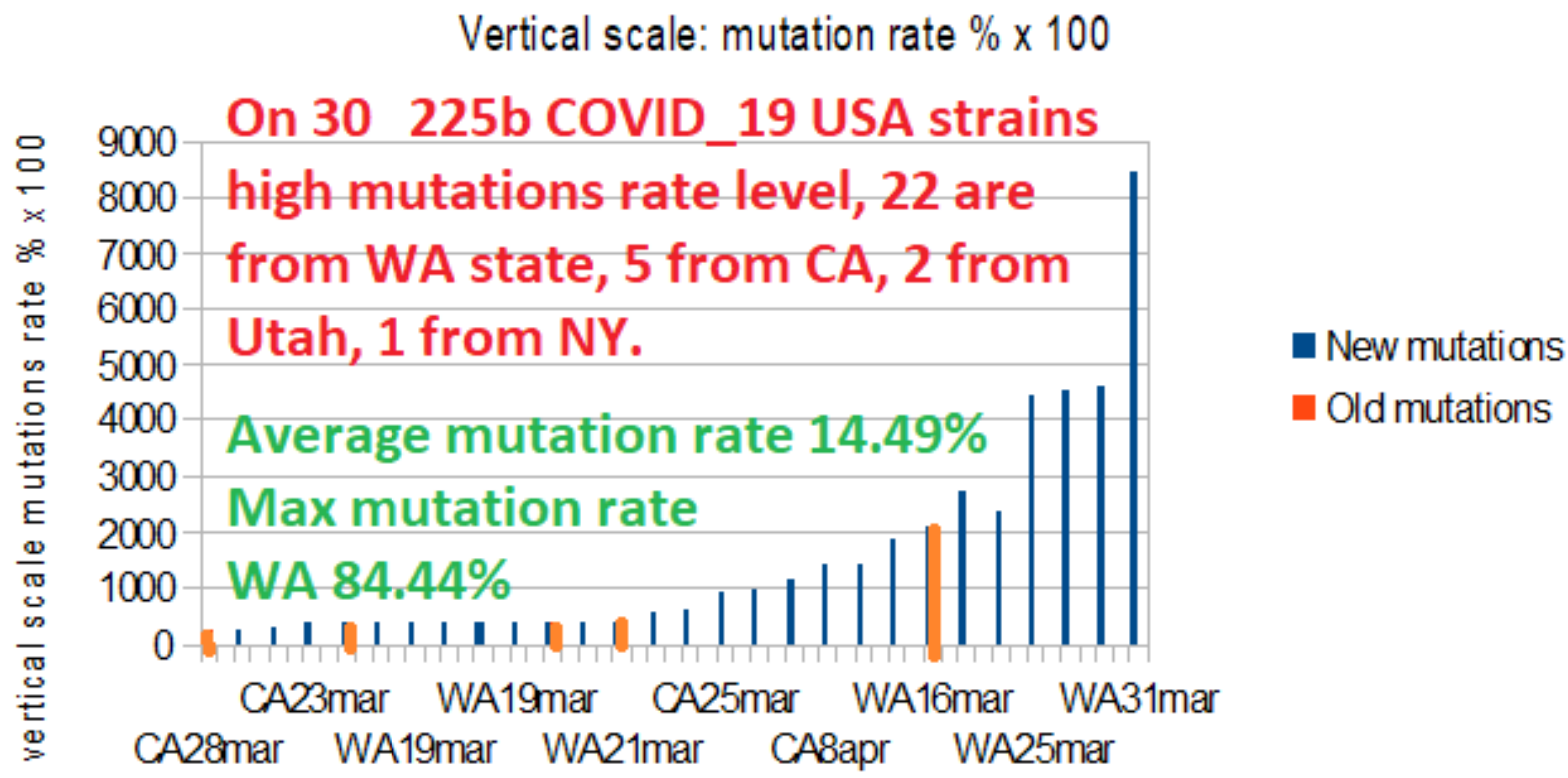

Reference strains and collection dates

In red color, we have located the 5 COVID_19 mutations rates from the above 2 (collected from NCBI data banks on 11 April 2020). After about 3 weeks (2 May 2020), the COVID_19 genomes sequences available has a bit increased. Then, we could conclude (blue colors) that USA COVID_19 genomes continue doing large deletions § mutations in critical 225bases region. In the same time, both amount and diversity of these mutations is increasing and evolving.

Particularly, the average mutation rate of these 30 COVID_19 individual patients is $14.49 \%$ with a maximum WA state deletion case with $84.44 \%$ mutation rate. 
A very interesting topic is discuting about the relative locations between the deletions/mutations locatios and the relative locations of the 4 EIE involved in this 225 bases region :

HIV1 Kenya 2008

$131 \quad$ Nucleotides adresses within region 225 bases

HIV2 Cap verde 2012

42. 59 Nucleotides adresses within region 225 bases

HIV2 Cote d' ivoire 2014

195. 214. Nucleotides adresses within region 225 bases

SIV Africa 2016

205. 226 Nucleotides adresses within region 225 bases

Locations of the 4 EIE within the 225bases region (bold) within Wuhan market ID: LR757998.1 ref [21542 on 225 bases]

111111111111111111111111111111

111111111111111111111111111111

111111111111111111111111111111

111111111111111111111111111111

111111111111111111111111111111

111111111111111111111111111111

111111111111111111111111111111 111111111111111

\section{Kenya HIV1}

Cap verde HIV2

2 last HIV2 and SIV have a partial overlap.

A detailed scanning of Table10 (Mutations/deletions column) reveals these intersting data :

Eleven (11) repeated cases of 9bases mutations are located between 188-197 or 189-198, then they " cut » the final HIVISIV region starting in base 195. Others big deletions destroys systematically the 2 starting EIE region (1-59) or the 2 end EIE region (195-225) : i.e Del 32 bases 194-225 and Del 32 bases 1-32 (which destroys exactly HIV1 Kenya EIE). Others bigger deletions erase half (begin or end) sections of the 225bases region : i.e Del 99 bases 1-99, Del 102 bases 124-225 etc... Finally, 20 cases on 30 analyzed USA mutations strains destroy partially or totally
one or more within the 4 HIVISIV EIE regions.

\section{Part IV/IV}

The comparative analysis of the SPIKES genes of COVID_19 and Bat RaTG13.

\section{1 - The region 1770 bases of the 2 proteins SPIKE in COVID_19 and Bat RaTG13.}

We will be interested in the sequences of the 2 respective SPIKE proteins of COVID_19 (reference genome used in the article) and Bat RaTG13.The relative addresses are respectively: SPIKBAT: address in Bat RaTG13 of address 21545 on 3810 bases.

SPIKCOV: address in COVID_19 (ref 998) of address 21538 on 3822 bases.

The comparative analysis of these 2 SPIKES sequences highlights the following partition:

A first common region between bases 1 and 2040.

Then, for Spike COVID_19 only, an insertion of 12 bases (CCTCGGCGGGCA) corresponding to the 4 amino acids "PRRA" (Pro, Arg, Arg, and Ala).

Then comes a second common region of 1,770 bases: Located from 2041 on 1770 bases for Bat RaTG13.

And located from 2053 to 1770 bases for COVID_19. 
We are then confronted with two "inexplicable anomalies" by natural causes of biological type: On the one hand, such a cost insert of 4 amino acids, if it can be inserted by CRISP RNA type technologies, will have great difficulty in finding a natural explanation.

By what natural process can a small fragment of 12 nucleotides of RNA integrate into the middle of a long genome with nearly 30,000 bases of RNA?

On the other hand, when comparing for these 2 pairs of regions the synonymous mutations and the non synonymous mutations, an abnormal fact will be highlighted for the second of the regions, that of 1770 bases.

The first region of 2040 bases (680 amino acids) common to the SPIKES of COVID_19 and Bat RaTG13:The 2 sequences are differentiated by 172 nucleotide mutations.

Let's finally:

155 different codons.

101 synonymous codons.

For 54 non-synonymous codons.

Then a ratio "Codons synonyms" / "Codons not synonyms" $=101 / 54=1.8703$.

Therefore, bases involved in "synonymous codons" / bases involved in synonymous codons "= 5.611.

This value close to the ratio "5" corresponds to the standard usually encountered in natural genetic sequences.

The second region of 1770 bases (590 amino acids) common to the SPIKES of COVID_19 and Bat RaTG13: The 2 sequences are differentiated by 90 nucleotide mutations.

Let's finally:

89 different codons.

83 synonymous codons.

For 6 non synonymous codons ONLY.

Either a ratio "Codons synonyms" / "Codons not synonyms" = 83/6 $=13.8333$

Therefore, bases involved in "synonymous codons" / bases involved in synonymous codons "= 41.499.

Let a ratio of 7.396 between these 2 respective ratios non synonymous codons / synonymous codons.

These 6 amino acid mutations therefore represent an "abnormal" level because the ratio of synonymous codons / non-synonymous codons $<42$ is completely ANORMAL This suggests the possible manipulation of this region of the COVID_19 genome.

" WHY " ?

Figure 10 below illustrates these "abnormal" results .

And it is the following $\S$ which will bring us an unexpected answer to this question ...

Comparing SPIKES in COVID_19 and Bat RaTG13: First region 680 AA

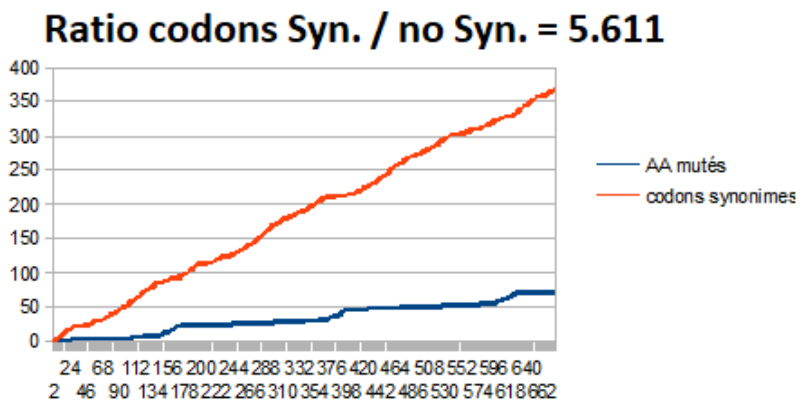

Comparing SPIKES in COMD_19 and Bat RaTG13: 2nd region 590AA

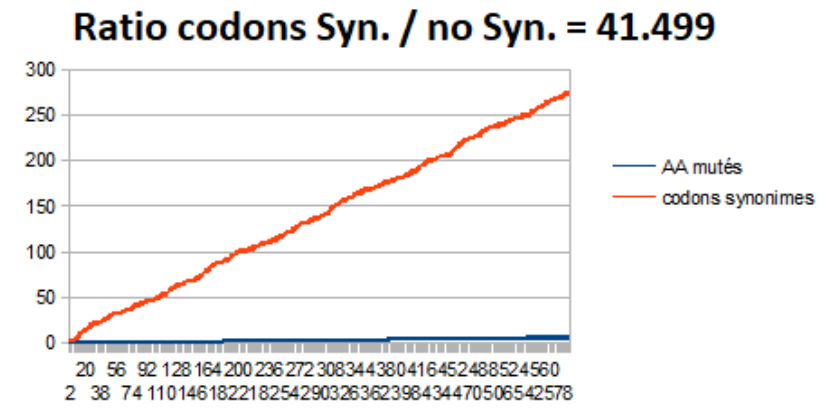

comparison of the evolution of synonymous and non-synonymous codons upstream (left) and downstream ( right) of the 4 amino acid insert in the COVID_19 Spike

Figure 10 - comparison of synonymous and non-synonymous mutations between the Spikes of cOVID_19 and Bat RaTG13 


\section{2 - Evidence of a significant EIE of Plasmodium Yoelii in the 1770 bases SPIKE region.}

The search for possible EIEs in COVID_19 and Bat RaTG13, both at the level of whole genomes, of the protein Spike, or of the critical region of 1770 bases highlights different candidate EIEs (see supplementary materials). The analysis of the region of 1770 bases more particularly reveals an EIE with a high probability BLASTn, moreover, the analysis via the Master Code points to a very probably precise functional site in this same region located towards the relative address 300 (100 amino acids (see supplementary materials ref 7):

\section{Plasmodium yoelii strain 17X genome assembly, chromosome: 10 Sequence ID: LM993664.2Length: 2065729Number of Matches: 2}

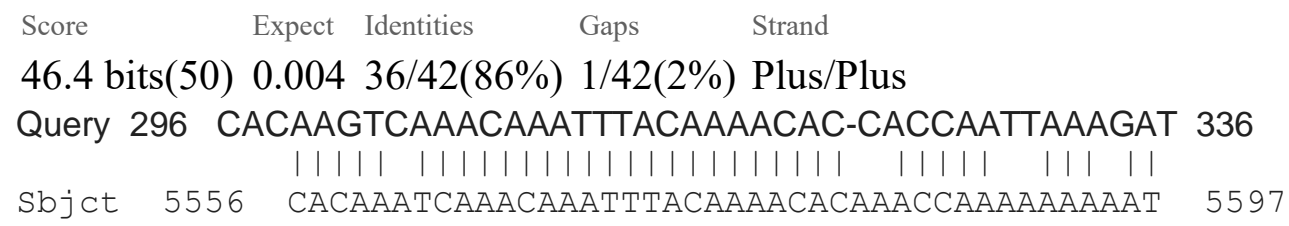

This EIE appears in several chromosomes of the plasmodium yoelii. In particular, it was quickly identified as a protein with the name "Fam a" Plasmodium yoelii "fam-a" protein (PY17X_0018000), partial mRNA Sequence ID: XM 022956016.1

We quickly confirm that it is indeed in these multiple homologies located in different chromosomes of plasmodium yoelii, the same protein "Fam a".

We should remember here that Plasmodium Yoelii is studied in mice in malaria vaccine strategies (ref).

An analysis of amino acid homologies confirms the very probable insertion of this EIE in COVID_19, in fact, 10 amino acids concentrated in a short sequence are homologous between COVID_19 and Plasmodium Yoelii protein "Fam a".

Analysis of the region in SPIKE Covid_19, located at the address $2052+295$ on 42 product bases:

CAC $\underline{\text { AAG }}$ TCA AAC AAA TTT ACA AAA CAC CAC CAA TTA $\underline{\underline{A A g}}$ ATT .../...

Either on the first reading frame of the codons:

\section{HIS LYS SER ASN LYS PHE THR LYS HIS HIS GLN LEU LYS ILE .../...}

We can easily verify that this codon reading frame is indeed that of the "Fam a" protein:

/product="fam-a protein

protein_id="XP_022810934.1"

/db_xref="GenēID:3801450"

/translation="MNIFFVQIVLFLLIISLCVNKNTLATELIPKKDKK

HKSNKFTKH KP K

KNKKCYPTYDNTKEIYQKN.../...

The homologous region on yoelii "Fam a", produces: 
Either on the first reading frame of the codons:

\section{HIS LYS SER ASN LYS PHE THR LYS HIS LYS PRO LYS LYS ASN......}

Or an almost perfect homology of amino acids despite 2 synonymous codons underlined here (AAG / AAA and AAG / AAA).

For information, the same analysis conducted on Bat RaTG13 produces:

CTC AAG TTA AAC AAA TTT ATA AGA CAC CAC CAA TTA AAG ATT .../...

\section{LEU LYS LEU ASN LYS PHE ILE ARG HIS HIS GLN LEU LYS ILE .../...}

The remarkable fact is the following: the amino acid homology between the region COVID_19 and Yoelii "Fam a" (10/14) is greater than that between Bat RaTG13 and yoelli "Fam a" (6/14), and equivalent to the homology between BatRaTG13 and COVID_19 (10/14).

Which is much less obvious as homology (6 amino acids instead of 10). Does this homology between COVID_19 and "Fam a" continue beyond? Indeed, an apparent continuity of this protein located downstream would extend this homology over a length of more than 60 bases:

Plasmodium yoelii genome assembly PYYM01, chromosome : 14 Sequence ID: LK934642.1Length: 2614191Number of Matches: 1

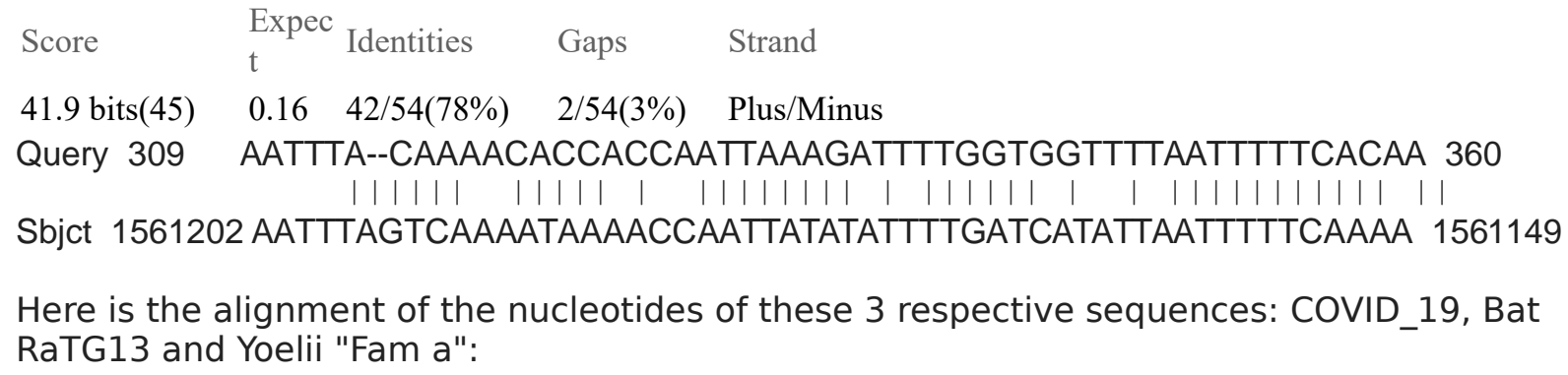

Therefore, the relative homologies in nucleotides, then in amino acids over this length extended to 63 bases, that is to say 21 amino acids lead to:

COVID_19 / Bat RaTG13 $=58 / 63 \mathrm{~b}$ et $16 / 21 \mathrm{AA}$ 
It is therefore clear that this second region of Yoelii does not coincide with the extension downstream of the sequence "Fam a", although concatenated with the fragment Yoelii "Fam a" in COVID_19, this region would come from another region (functional ?) from Plasmodium Yoelii ...

Comparing COD_19 and bat RaTG13 1770 bases SPIKE region

comparing nucleotides mutations numbers related position within codons

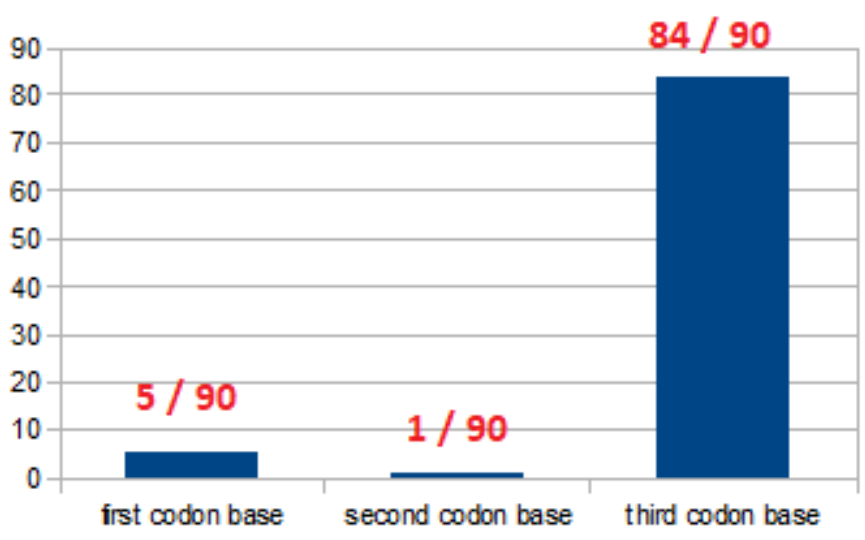

number mutations

Figure 11 - Evidence that the majority of the 90 nucleotide mutations between COVID_19 and Bat RaTG13 SPIKE region 1770 bases are located on the third bases of the codons.

The major conclusion of this demonstration of an EIE of the plasmodium Yoelii in COVID_19 is as follows: This very high amino acid homology score of 10/14 between covid / yoelii "Fam a" results from a shift in the reading frame of the spike codons. This explains the poorer score of the RaTG13 bat with respect to the yoelii which, however, is homologous in amino acids in this region which is very poor in amino acid mutations! So these are the basic mini mutations between COVID_19 and bat RaTG13 which made the difference here!

With this proof of yoelii, we obtain at the same time the explanation of this anomaly of the ratio codons synonyms / non-synonyms of the region 1770b highlighted previously. Indeed, as shown in Figure 11 above, the minor mutations do not change the amino acid values COVID_19 / batRaTG13 (almost always the 3rd base of synonymous codons).

We believe that this strategy of shifting the codon reading frame was probably used throughout this region of 1770 bases, for example in this location (relative to 1770 bases region):

1464 TAATGCTTCAGTTGTAAA-CATTCAAAAA 1491 with 93\% nucleotides homology, and a good amino acids homology considering the shift of codons reading frame. Effectively, this other EIE from plasmodium Yoelii also corresponds to a shifted position from the reading frame for Spike codons (see supplementary materials).

But with the change of the codon reading frame, a "synonymous" mutation on the Spike frame will become "not synonymous" on a second codon reading frame, which has just been demonstrated here, this is very precisely what who arrives here with this blatant proof of the fact that an EIE of the gene "Fam a" of the plasmodium Yoelii would have been inserted here using this "strategy for intelligent": while the 2 genes SPIKE of COVID-19 and Bat RaTG13 are almost identical according to their normal reading frame, a second reading frame radically differentiates the expression of the EIE "Fam a" between the 2 respective Spikes of COVID_19 and Bat RaTG13.

\section{3 - The analysis of deletions in the SPIKE critical region of 1770 bases in the USA WA state (Seattle).}

As we did above for the region 225 bases of COVID_19, we will ask ourselves here the same question: "The region of 1770 bases of Spike, and more particularly the EIE of Plasmodium Yoelii undergo strong deletions in genomes from USA patients from Washington State WA Seattle "?

\footnotetext{
Table 12 - 43 USA"WA state" individual patient genomes with deletions in the 1770 bases COVID_19 SPIKE region.
} 


\begin{tabular}{|c|c|c|}
\hline USA WA individual patient genome & Deletions & $\begin{array}{l}\text { Plasmodium Yoelii } \\
\text { deletions }\end{array}$ \\
\hline USA/WA-UW-5205/2020, complete genome Sequence ID: MT412257.1 & $6 \mathrm{del}$ & No \\
\hline USA/WA-UW-5182/2020, complete genome Sequence ID: MT412228.1 & $6 \mathrm{del}$ & No \\
\hline USA/WA-UW146/2020, complete genome Sequence ID: $\underline{\text { MT252737.1 }}$ & 8del & No \\
\hline USA/WA-UW273/2020, partial genome Sequence ID: $\underline{\text { MT259265.1 }}$ & $8 \mathrm{del}$ & No \\
\hline USA/WA-UW199/2020, complete genome Sequence ID: $\underline{\text { MT246456.1 }}$ & $13 \mathrm{del}$ & No \\
\hline USA/WA-UW280/2020, partial genome Sequence ID: $\underline{\text { MT259272.1 }}$ & $18 \mathrm{del}$ & No \\
\hline USA/WA-UW302/2020, partial genome Sequence ID: $\underline{\text { MT263385.1 }}$ & $21 \mathrm{del}$ & No \\
\hline USA/WA-UW373/2020, complete genome Sequence ID: $\underline{\text { MT263453.1 }}$ & $25 \mathrm{del}$ & $296-300$ \\
\hline USA/WA-UW386/2020, partial genome Sequence ID: $\underline{\text { MT263466.1 }}$ & $33 \mathrm{del}$ & $\begin{array}{ll}\text { Close upstream } \\
\text { Yoelii }\end{array}$ \\
\hline USA/WA-UW278/2020, partial genome Sequence ID: MT259270.1 & 38del & No \\
\hline USA/WA-UW306/2020, partial genome Sequence ID: $\underline{\text { MT263389.1 }}$ & 39del & No \\
\hline USA/WA-UW206/2020, partial genome Sequence ID: $\underline{\text { MT246463.1 }}$ & $44 d e l$ & $\begin{array}{l}301-313 \\
\text { and 322-336 }\end{array}$ \\
\hline USA/WA-UW289/2020, partial genome Sequence ID: $\underline{\text { MT259279.1 }}$ & $45 \mathrm{del}$ & $\begin{array}{l}\text { 301-313 and close } \\
\text { downstream Yoelii }\end{array}$ \\
\hline USA/WA-UW-6315/2020, complete genome Sequence ID: MT412323.1 & 46del & $\begin{array}{l}301-313 \text { and } \\
332-336\end{array}$ \\
\hline USA/WA-UW208/2020, partial genome Sequence ID: MT246465.1 & 66del & $\begin{array}{l}301-313 \text { and } \\
320-326 \text { and 330- } \\
336\end{array}$ \\
\hline USA/WA-UW312/2020, partial genome Sequence ID: MT263393.1 & 99del & No \\
\hline $\begin{array}{l}\text { USA/WA-UW-4538/2020, complete genome Sequence } \\
\text { ID: MT375428.1 }\end{array}$ & 129del & Totally deleted \\
\hline USA/WA-UW347/2020, partial genome Sequence ID: MT263427.1 & 198del & Totally deleted \\
\hline USA/WA-UW157/2020, complete genome Sequence ID: MI252730.1 & 167del & Totally deleted \\
\hline $\begin{array}{l}\text { USA/WA-UW-4707/2020, complete genome Sequence } \\
\text { ID: MT375462.1 }\end{array}$ & 180del & No \\
\hline USA/WA-UW379/2020, partial genome Sequence ID: MT263409.1 & $361 \mathrm{del}$ & Totally deleted \\
\hline USA/WA-UW246/2020, partial genome Sequence ID: $\underline{\text { MT259238.1 }}$ & $413 \mathrm{del}$ & $322-336$ \\
\hline USA/WA-UW267/2020, partial genome Sequence ID: $\underline{\text { MT259259.1 }}$ & 390del & Totally deleted \\
\hline Summary & $\begin{array}{l}23 \text { deletions } \\
\text { / } 23 \text { cases }\end{array}$ & $\begin{array}{l}12 \text { undeleted, } \\
6 \text { partially deleted, } \\
5 \text { totally deleted }\end{array}$ \\
\hline
\end{tabular}

Note: we have selected here the last 23 WA (Seattle) genomes resulting from a BLASTn search carried out on the 1770 bases region on the GENBANK COVID_19 sequences public database on May 27, 2020.

Complete details in supplementary materials (ref 8 ). 
It appears here very clearly that these genomes of the USA WA state (Seattle) region seem to try to "rid" of these EIE regions: indeed, of these 23 genomes analyzed, almost half have eliminated, partially (6) or totally (5), this region suspected of containing a EIE of plamodium Yoelii.

This second proof, with that relating to the 225 bases region, tends to demonstrate that the COVID_19 genome tends to eliminate exogenous regions in priority. It can therefore be suggested that, as a result, the infectivity and pathogenicity of the virus gradually decrease over time ...

\section{CONCLUSIONS :}

1) 18 RNA fragments of homology equal or more than $80 \%$ with human or simian retroviruses have been found in the COVID_19 genome.

2) These fragments are 18 to 30 nucleotides long and therefore have the potential to modify the gene expression of Covid19. We have named them external Informative Elements or EIE.

3) These EIE are not dispersed randomly, but are concentrated in a small part of the genome.

4) Among this part, a 225 nucleotide long region is unique to COVID_19 and Bat RaTG13 and can discriminate and formally distinguish these 2 genomes.

5) In the decreasing slope of the epidemic, this region exhibits an abnormally high rate of mutations/deletions.

6) The comparative analysis of the SPIKES genes of COVID_19 and Bat RaTG13 demonstrates two abnormal facts: on the one hand, the insertion of 4 contiguous amino acids in the middle of SPIKE, on the other hand, an abnormal distribution of synonymous codons in the second half of SPIKE. Finally the insertion in this region of an EIE coming from a Plasmodium Yoelii gene is demonstrated, but above all seems to explain the "strategy" pursued by having "artificially" modified the ratio of synonym codons I nonsynonymous codons in this same region of 1770 COVID_19 SPIKE nucleotides.

\section{REFERENCES :}

1.WHO-SARS, https: / /www. google.com/url?

sa=t\&source=web\&rct=j\&url=https://www.who.int/ith/diseases/sars/en/\&ved=2ahUKEwiYufHk5tDo AhXU3OUKHSTwBUYQFjAWegQIBRAB\&Usg=AOvVaw0bFOEUPELafXU98baC402k

2.WHO-MERS, https://www.google.com/url?sa=t\&source=web\&rct=j\&url=https://www.who.int/emergencies/merscov/en/\&ved=2ahUKEwjigPe059DoAhXEx4UKHU5xDDYQFjAMegQIBBAC\&usg=AOvVaw1kaYVgLwAr9c7EyL7kGXQn 3.Perez, J.C, 2020/02/13, Wuhan nCoV-2019 SARS Coronaviruses Genomics Fractal Metastructures Evolution and Origins, DO -DOI: 10.20944/preprints202002.0025.v2, Researchgate : https://www.researchgate.net/publication/339331507 Wuhan nCoV-

2019 SARS Coronaviruses Genomics Fractal Metastructures_Evolution_and_Origins

4.Lyons Weiler J., 2020, 1-30-2020, On the origins of the 2019 ncov virus wuhan china, https: //jameslyonsweiler.com/2020/01/30/on-the-origins-of-the-2019-ncov-virus-

wuhan-china/

5.Perez J.C, (2020). "WUHAN COVID-19 SYNTHETIC ORIGINS AND EVOLUTION." International Journal of Research - Granthaalayah, 8(2), 285-324. https://doi.org/10.5281/zenodo.3724003.

6.Perez J.C, Codex biogenesis - Les 13 codes de l'ADN (French Edition) [Jean-Claude ... 2009); Language:

French; ISBN-10: 2874340448; ISBN-13: 978-2874340444

7.Perez J.C, Deciphering Hidden DNA Meta-Codes -The Great Unification \& Master Code of Biology. J Glycomics Lipidomics 5:131, 2015, doi: 10.4172/2153-0637.1000131 https://www.omicsonline.org/openaccess/deciphering-hiddendna-metacodesthe-great-unification--mastercode-ofbiology-2153-0637- 1000131.php?aid=55261

8.Perez, J.C. Six Fractal Codes of Biological Life:perspectives in Exobiology, Cancers Basic Research and Artificial Intelligence Biomimetism Decisions Making. Preprints 2018, 2018090139 (doi: 10.20944/preprints201809.0139.v1). https://www.preprints.org/manuscript/201809.0139/v1

9.Land A.M. Et al, Human immunodeficiency virus (HIV) type 1 proviral hypermutation correlates with CD4 count in 
HIV-infected women from Kenya., J Virol. 2008 Aug;82(16):8172-82. doi: 10.1128/JVI.01115-08. Epub 2008 Jun 11., DOI: 10.1128/JVI.01115-08 https://www.ncbi.nlm.nih.gov/pubmed/18550667

10.Venkatesan P, Franck Alla Plummer, The Lancet Infectious diseases, April 2020,

DOI: https://doi.org/10.1016/S1473-3099(20)30188-2, https://www.thelancet.com/pdfs/journals/laninf/PIIS14733099(20)30188-2.pdf

11.Perez, J. Epigenetics Theoretical Limits of Synthetic Genomes: The Cases of Artificials Caulobacter (C. eth-2.0), Mycoplasma Mycoides (JCVI-Syn 1.0, JCVI-Syn 3.0 and JCVI_3A), E-coli and YEAST chr XII. Preprints 2019,

2019070120 (doi:10.20944/preprints201907.0120.v1).https://www.preprints.org/manuscript/201907.0120/v1

12.Zhou, P et al, 2020, A pneumonia outbreak associated with a new coronavirus of probablebat origin, Nature 579 (7798), 270-273 (2020), DOI: $\underline{10.1038 / s 41586-020-2012-7}$

13.FISABIO, 2020,

http://fisabio.san.gva.es/web/fisabio/noticia/-/asset publisher/1vZL/content/secuenciacioncoronavirus.

14.Andersen, K.G., Rambaut, A., Lipkin, W.I. et al. The proximal origin of SARS-CoV-2. Nat Med (2020). https://doi.org/10.1038/s41591-020-0820-9

15.Prashant Pradhan et al, Uncanny similarity of unique inserts in the 2019-nCoV spike protein to HIV-1 gp120 and Gag,https://www.biorxiv.org/content/10.1101/2020.01.30.927871v1

16.Yuanchen Ma et al., 2020-2-27, ACE2 shedding and furin abundance in target organs may influence the efficiency of SARS-CoV-2, http://www.chinaxiv.org/abs/202002.00082

17.Xiaolu Tang, Changcheng Wu, Xiang Li, Yuhe Song, Xinmin Yao, Xinkai Wu, Yuange Duan, Hong Zhang, Yirong Wang, Zhaohui Qian, Jie Cui, Jian Lu, On the origin and continuing evolution of SARS-CoV-2, National Science Review, , nwaa036, https://doi.org/10.1093/nsr/nwaa036

18.Lu, R et al., 2020. Genomic characterisation and epidemiology of 2019 novel coronavirus: implications for virus origins and receptor binding The Lancet. https://www.thelancet.com/journals/lancet/article/PIISO1406736\%2820\%2930251-8/fulltext

19.Wei Ji, et al, Homologous recombination within the spike glycoprotein of the newly identified coronavirus 2019-nCoV may boost cross-species transmission from snake to human, https://onlinelibrary.wiley.com/doi/pdfdirect/10.1002/jmv.2568220.

20.Peng Zhou et al, Discovery of a novel coronavirus associated with the recent pneumonia outbreak in humans and its potential bat origin, BioRxiv, January 2020, https://doi.org/10.1101/2020.01.22.914952

21.Leoz M, Feyertag F, Kfutwah A, Mauclère P, Lachenal G, et al. (2015) The Two-Phase Emergence of Non Pandemic HIV-1 Group O in Cameroon. PLOS Pathogens 11(8):

e1005029. https://doi.org/10.1371/journal.ppat.1005029

22. Hangping Yao, et al., Patient-derived mutations impact pathogenicity of SARS-CoV-2 medRxiv 2020.04.14.20060160; doi: https://doi.org/10.1101/2020.04.14.20060160

23. David B. T. Cox et al., RNH editing with CRISPR-Cas13, Science 24 Nov 2017: Vol. 358, Issue 6366, pp. 10191027, DOI: $10.1126 /$ science.aaq0180

24. LaRinda A. Holland et al, An 81 nucleotide deletion in SARS-CoV-2 ORF7a identified from sentinel surveillance in Arizona (Jan-Mar 2020), Journal of Virology (2020). DOI: 10.1128/JVI.00711-20

24. Xue Wu Zhang et al, Structural similarity between HIV1 gp41 and SARS-CoV S2 proteins suggests an analogous membrane fusion mechanism May 2004Journal of Molecular Structure THEOCHEM 677(1):73-76,

DOI: $10.1016 /$ j.theochem.2004.02.018 